
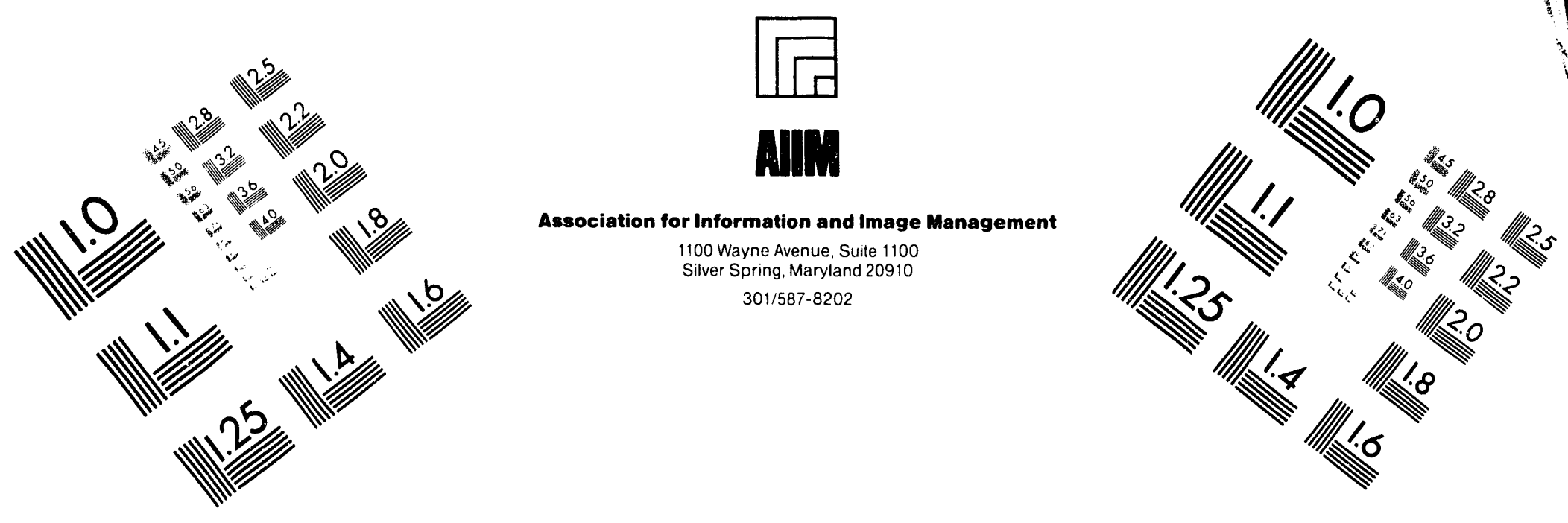

Centimeter

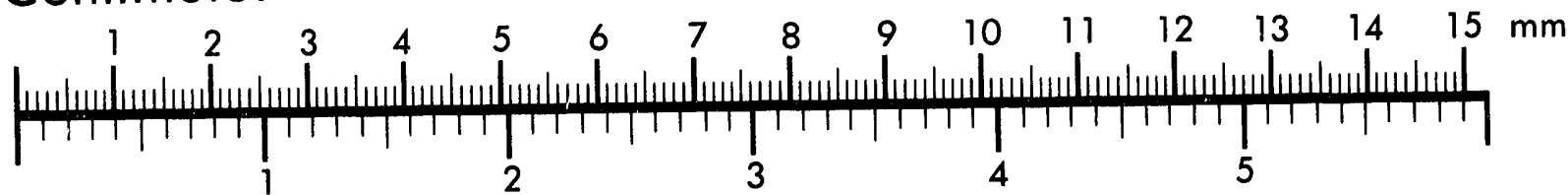

Inches
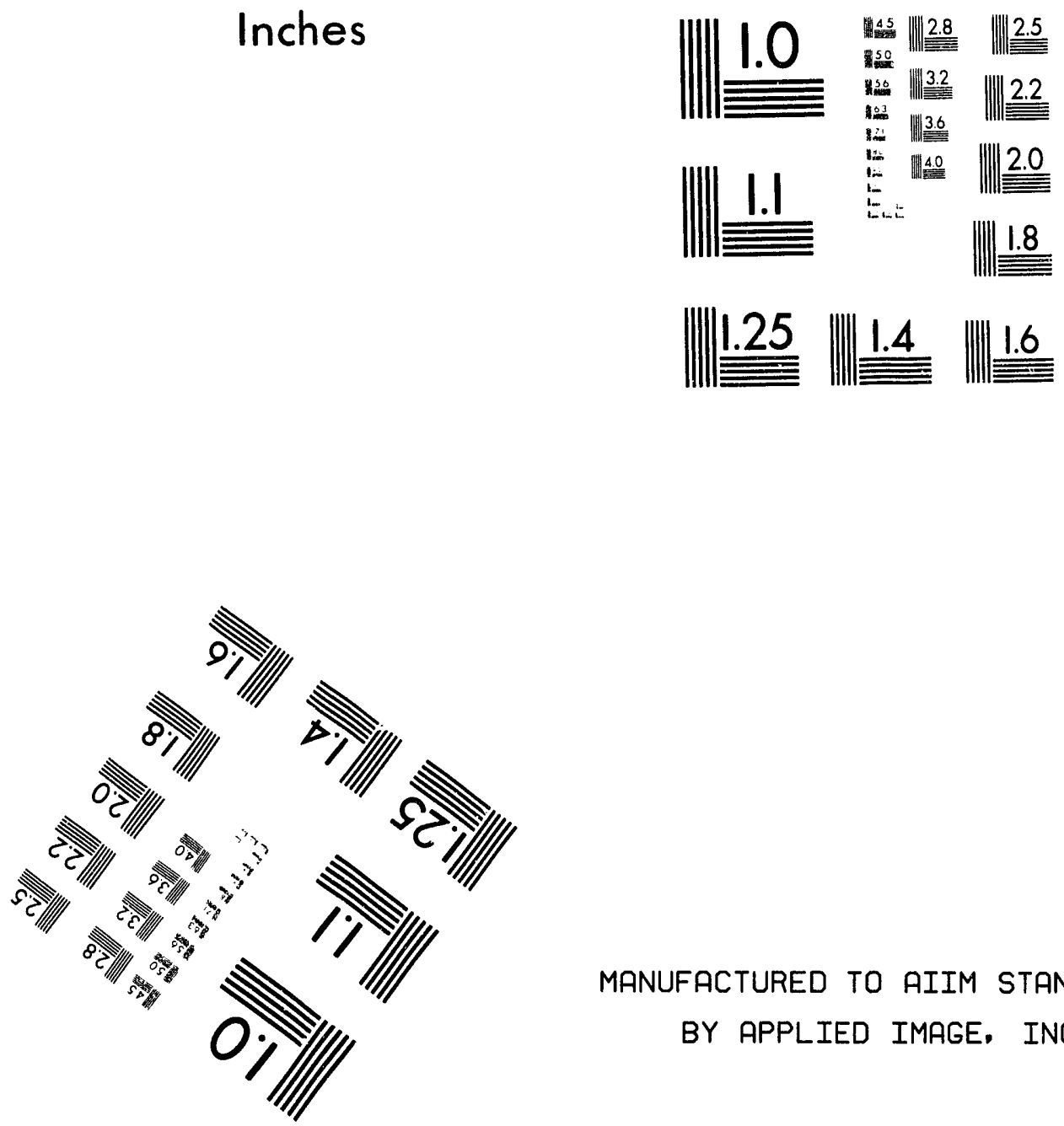

MANUFACTURED TO AIIM STANDARDS

BY APPLIED IMAGE, INC.

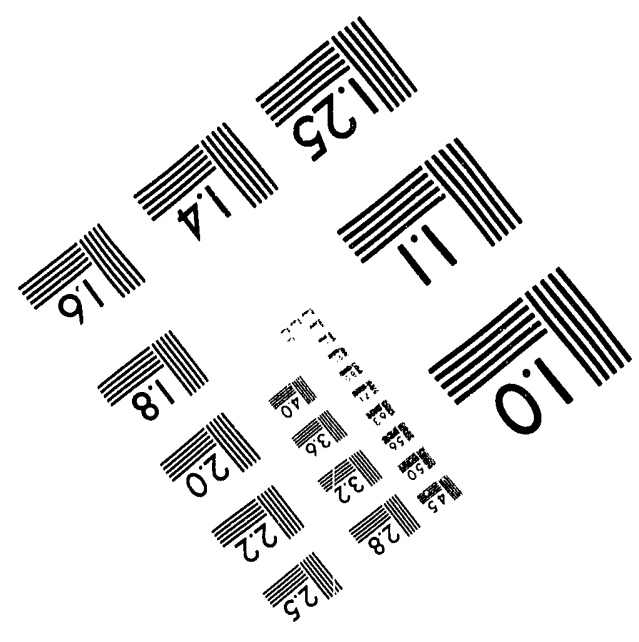



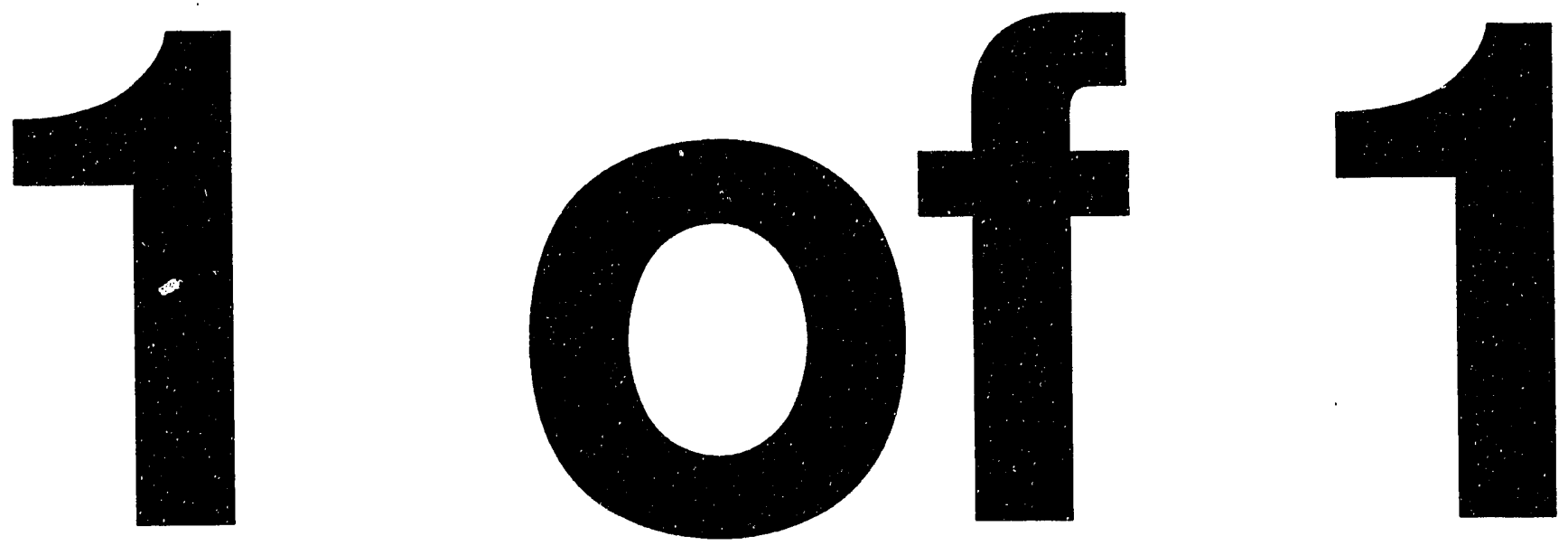


\title{
Test Plan for the Retrieval Demonstration
}

\author{
D. J. Valentich
}

Published May 1993

Caterpillar, Inc.

Defense and Federal Products

100 NE Adams Street

Peoria, Illinois 61629

\author{
Martin Marietta \\ Aero \& Naval Systems \\ 103 Chesapeake Park Plaza \\ Baltimore, Maryland 21220
}

Prepared for EG\&G Idaho, Inc. and

the U.S. Department of Energy

Office of Environmental Restoration and Waste Management

Under DOE Idaho Fleld Office

Contract DE-AC07-76ID01570

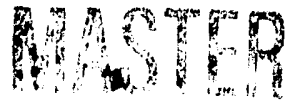


Test Plan for the Retrieval Demonstration

EGG-WTD-10744

Prepared by

Din J. Volertich

$4-27-93$

D. J. Valentich

Date

Reviewed by

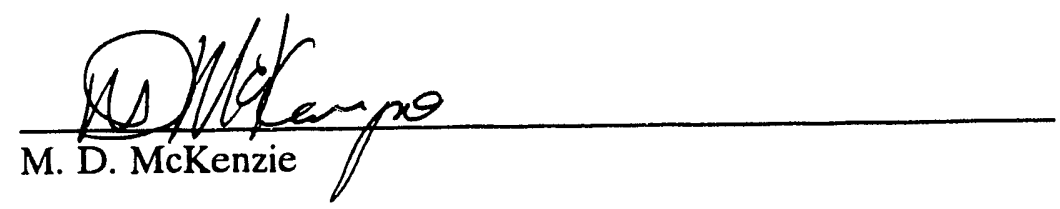

$\frac{4-2793}{\text { Date }}$

Approved by

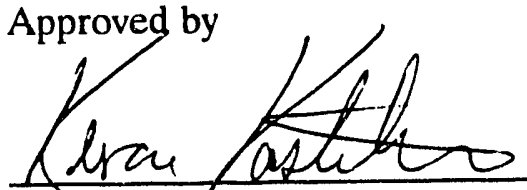

K. M. Kostehik

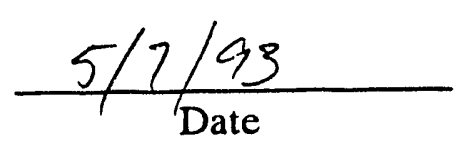




\begin{abstract}
This test plan describes a simulated buried waste retrieval demonstration that will be performed at the Caterpillar, Inc., Edwards Training Center located near Peoria, Illinois. The purpose of the demonstration is to determine the effectiveness of using readily available excavation equipment to retrieve, size, and handle various simulated waste forms that are similar in size, structure, and composition to those expected to be found in U.S. Department of Energy contaminated waste pits and trenches. Test objectives, detailed procedures, data quality objectives, and documentation methods are included in this plan.
\end{abstract}




\section{SUMMARY}

This test plan describes a simulated buried waste retrieval demonstration. The purpose of the demonstration is to determine the effectiveness of using readily available excavation equipment to retrieve, size (at the dig face), and handle various simulated waste forms. The demonstration is being conducted by Caterpillar, Inc. under contract to EG\&G Idaho, Inc., who is managing the work for the U.S Department of Energy (DOE) Office of Technology Development as part of the Buried Waste Integrated Demonstration (BWID) program. The BWID program is investigating the feasibility of new and existing technologies for the effective in situ treatment, removal, and treatment after removal of buried wastes. A major thrust of the program is to evaluate which readily available state-of-the-art equipment and methods are suitable for exhumation of buried waste found in contaminated pits and trenches located throughout the DOE complex.

The objectives of this demonstration are to

1. Meet and maintain daily production goals of $80 \mathrm{yd}^{3} /$ day.

2. Minimize spillage and dust gerieration through careful and deliberate operations.

3. Document and evaluate methods for manipulating, sizing, and/or working around large objects.

4. Document and evaluate requirements for operator augmentation and remote operation for hot test pit excavation operations.

Four conditions comprising the range of environments to be evaluated include excavation of

1. Random material from belowgrade

2. Stacked boxes and barrels from belowgrade

3. Random materials from at grade

4. Stacked boxes and barrels from at grade.

Data needed to compare the four basic demonstration conditions will be collected and recorded during operations and analyzed in a "quick look" report after completing of daily operations. Detailed analyses of the final data set will include descriptive statistics and inferential analyses ${ }^{a}$ appropriate to the level of measurement, supported by video and still photography.

Results of the retrieval demonstration will reduce unknowns (production capability, dust generation, and ease of operation) in the body of knowledge about retrieval equipment and procedural options for removal of buried transuranic (TRU) waste at the Idaho National Engineering

a. Inferential analysis is a method used to quantify and improve the confidence level of interpretive data. 
Laboratory. It is anticipated that DOE will factor this information into a remedial investigation/feasibility plan leading to a final record of decision for disposition of buried TRU waste. 


\section{CONTENTS}

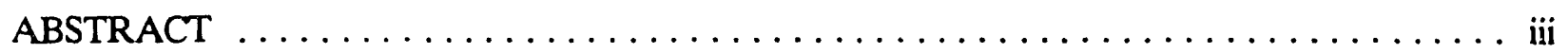

SUMMARY $\ldots \ldots \ldots \ldots \ldots \ldots \ldots \ldots \ldots \ldots \ldots \ldots \ldots \ldots \ldots \ldots \ldots \ldots \ldots$

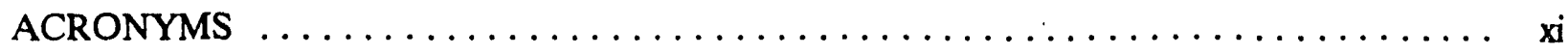

ACKNOWLEDGMENTS $\ldots \ldots \ldots \ldots \ldots \ldots \ldots \ldots \ldots \ldots \ldots \ldots \ldots \ldots \ldots \ldots \ldots \ldots \ldots \ldots$ xiii

1. INTRODUCTION $\ldots \ldots \ldots \ldots \ldots \ldots \ldots \ldots \ldots \ldots \ldots \ldots \ldots \ldots \ldots \ldots \ldots \ldots \ldots$

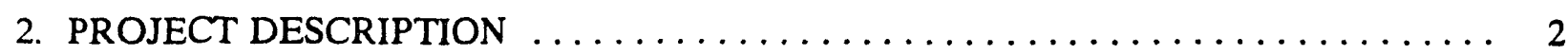

2.1 Background Information $\ldots \ldots \ldots \ldots \ldots \ldots \ldots \ldots \ldots \ldots \ldots \ldots \ldots \ldots \ldots \ldots \ldots \ldots, 2$

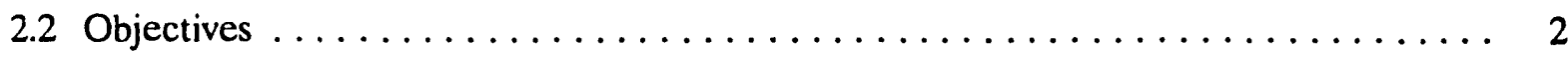

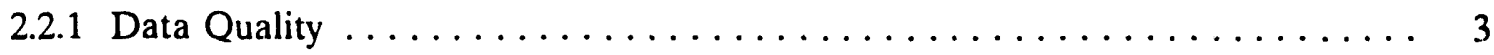

2.2.2 Basis for Data Quality .......................... 4

3. PROJECT ORGANIZATION $\ldots \ldots \ldots \ldots \ldots \ldots \ldots \ldots \ldots \ldots \ldots \ldots \ldots \ldots \ldots \ldots \ldots$

4. DEMONSTRATION AND EVALUATION PLAN $\ldots \ldots \ldots \ldots \ldots \ldots \ldots \ldots, 8$

4.1 Cold Tiest Pit Configuration and Waste Forms $\ldots \ldots \ldots \ldots \ldots \ldots \ldots$

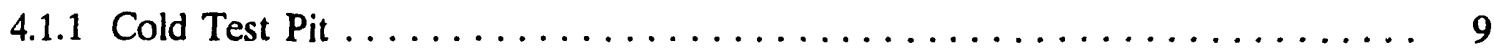

4.1.2 Waste Forms and Placement $\ldots \ldots \ldots \ldots \ldots \ldots \ldots \ldots \ldots \ldots \ldots \ldots$

4.1.3 Cold Test Pit Configuration and Construction ............... 9

4.2 Excavation and Material Handling Concepts $\ldots \ldots \ldots \ldots \ldots \ldots \ldots \ldots \ldots \ldots$

4.3 Operator Augmentation Concepts (Camera, Displays, etc.) $\ldots \ldots \ldots \ldots \ldots \ldots$

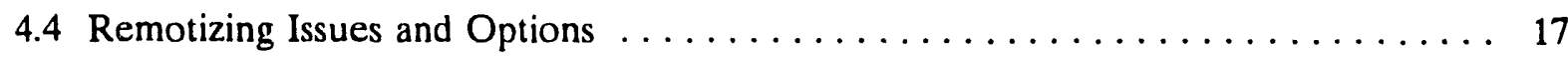

5. DEMONSTRATION PROCEDURES $\ldots \ldots \ldots \ldots \ldots \ldots \ldots \ldots \ldots \ldots \ldots \ldots \ldots \ldots \ldots$

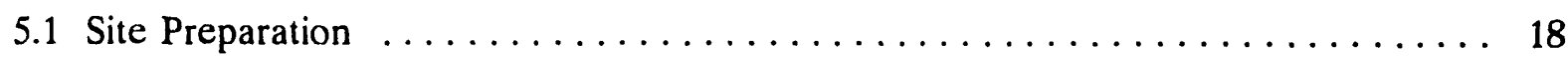

5.2 Dig Face Removal and Sizing Methods $\ldots \ldots \ldots \ldots \ldots \ldots \ldots \ldots \ldots \ldots$

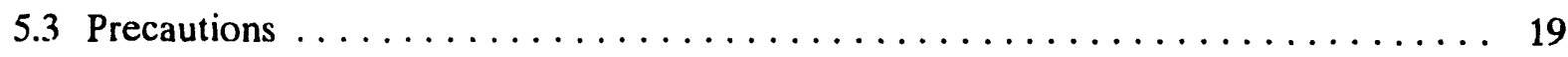

5.4 Demonstration Operations and Evaluation Objectives $\ldots \ldots \ldots \ldots \ldots \ldots \ldots$ 


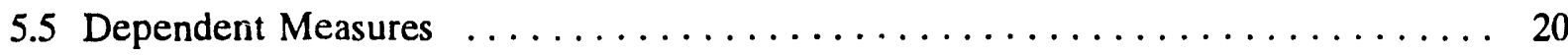

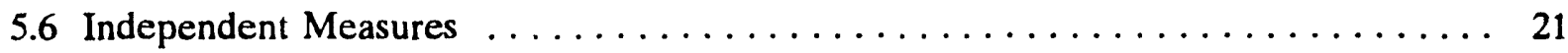

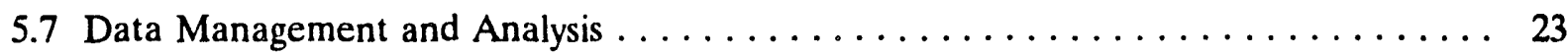

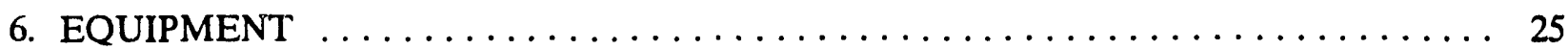

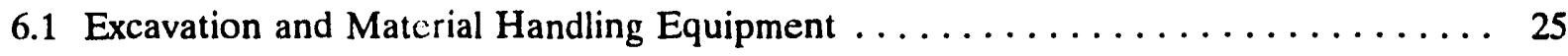

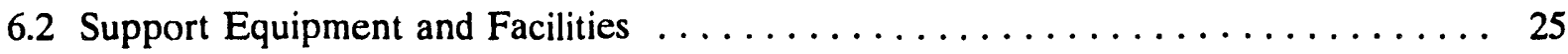

6.3 Maintenance, Operation, and Calibration of Equipment $\ldots \ldots \ldots \ldots \ldots \ldots 26$

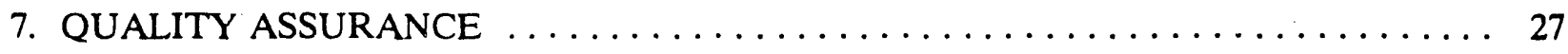

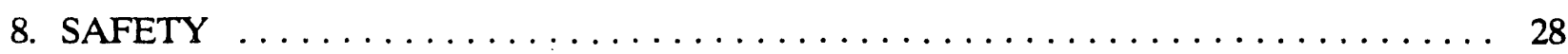

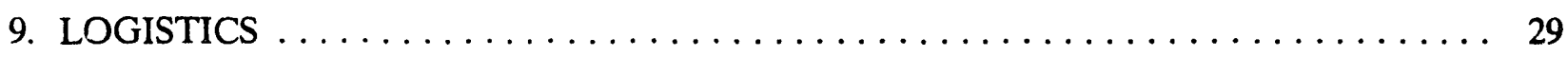

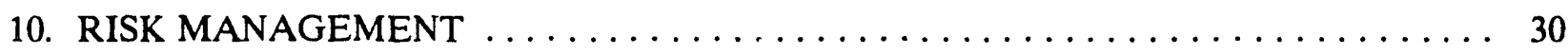

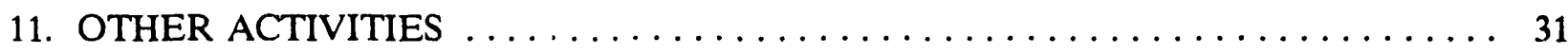

11.1 Measurement of Excavated Quantities $\ldots \ldots \ldots \ldots \ldots \ldots \ldots \ldots \ldots \ldots \ldots \ldots \ldots$

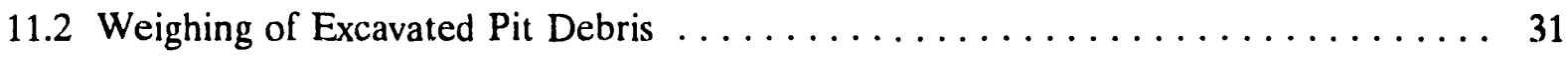

11.3 Disposal of Simulated Buried Waste $\ldots \ldots \ldots \ldots \ldots \ldots \ldots \ldots \ldots \ldots \ldots \ldots$

11.4 Document Control ................................ 31

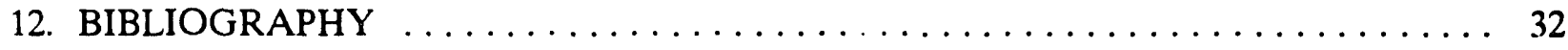

Appendix A-Requirements Verification Matrix Retrieval Demonstration $\ldots \ldots \ldots \ldots$ A-1

FIGURES

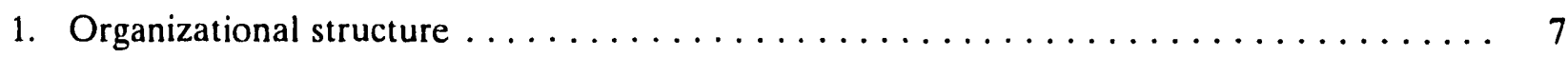

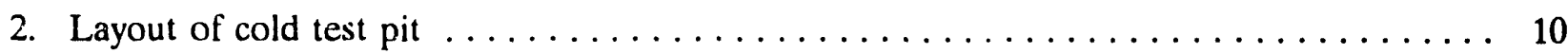

3. Plan and elevation views of the random dumped boxes and drums and large objects cell . . 11 
4. Plan and elevation views of the stacked boxes and drums cell $\ldots \ldots \ldots \ldots \ldots \ldots$

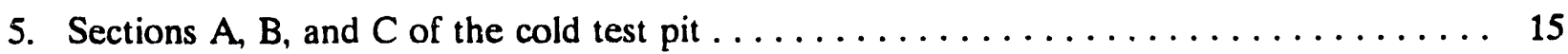

\section{TABLE}

1. Measurement error tolerances 


\section{ACRONYMS}

BWID Buried Waste Integrated Demonstration

CAT Caterpillar, Inc.

CCTV Closed circuit television

DOE U.S. Department of Energy

ES\&H Environment, Safety, and Health

ETC Edwards Training Center, Peoria, Illinois

HEX Hydraulic excavator

INEL Idaho National Engineering Laboratory

MMA\&NS Martin Marietta Aero \& Naval Systems

MOE Measure of effectiveness

OTD Office of Technology Development

ROM Rough order of magnitude

SDA Subsurface Disposal Area

T\&E $\quad$ Test and evaluation

TRU Transuranic 


\section{ACKNOWLEDGMENTS}

Thanks is given to Dr. Thomas M. Cook of Martin Marietta who has written the majority of this document. Mr. Brian D. McFeeters of Caterpillar has also contributed to the development of this test plan. 


\section{Test Plan for the Retrieval Demonstration}

\section{INTRODUCTION}

This test plan describes the test and evaluation (T\&E) of a simulated buried waste retrieval demonstration that will be performed at the Caterpillar, Inc. (CAT), Edwards Training Center (ETC) in Peoria, Illinois, during the summer of 1993 for the U.S Department of Energy (DOE). Specific equipment and procedures to be evaluated, construction of the ccld test pit, specific retrieval methods, recording test information, and analysis and reporting of T\&E results are described.

Throughout the DOE complex considerable field testing has been performed with a variety of characterization, treatment, and removal technologies associated with remediating transuranic (TRU) buried waste pits and trenches. To date, however, a large scale field test using commercially available conventional type equipment has not been conducted. The proposed dernonstration will determine the effectiveness of using this type of equipment for the removal of buried waste. 


\section{PROJECT DESCRIPTION}

The retrieval demonstration is being performed as a part of the Buried Waste Retrieval Demonstration (BWID) program. The BWID program examines promising approaches, methods, and technologies for demonstration purposes and develops new technologies for application to DOE sites' waste problems.

This demonstration will determine which readily and commercially available state-of-the-art equipment (CAT hydraulic excavators, integrated tool carrier, and tracked loader) is effective for the exhumation of buried TRU mixed waste. It is anticipated that some types of waste material will be relatively easy to excavate and handle whereas other types, such as steel shapes and wire cable, may be more difficult and require coordinated operations. While not specifically evaluated as a part of this demonstration, remote equipment operations will be considered in analyzing equipment performance and task difficulty, addressing requirements for future remotized systems, and discussing this topic in the project final report.

All information, data, and analyses performed in support of this work will be documented in a report and two final video tapes. Both the report and videos will be formally issued before October 1993.

\subsection{Background Information}

The waste forms to be included in the cold test pit for this demonstration closely resemble the over 2 million cubic feet of TRU mixed waste that was buried in shallow pits and trenches in the Idaho National Engineering Laboratory's (INEL's) Subsurface Disposal Area (SDA) between 1952 and 1970. This waste is considered typical of other TRU waste buried in pits and trenches throughout DOE sites. Commingled with the TRU waste is over 8 million cubic feet of potentially contaminated fill dirt. The waste containers are considered to be severely deteriorated to the point where containers are breached, leaking, or completely deteriorated.

This demonstration will play a significant role in determining which suite of conventional excavation methods and equipment are needed for the range of operations required for retrieving contaminated buried waste.

\subsection{Objectives}

The primary objective of this demonstration is to evaluate the effectiveness of the chosen suite of CAT equipment for retrieving waste forms that are typical of buried TRU waste at the INEL and other DOE sites. A boundary case for the removal of buried waste will be established by utilizing highly experienced CAT equipment operators, as well as the optimum selection of excavation type equipment and end effectors. A successful demons ation will be determined when the equipment operator can retrieve and handle buried waste, larg. :sbjects, and soil (away from the dig face) at a rate of $80 \mathrm{yd}^{3} /$ day ( 8 hour shift) while minimizing the spread of dust. 


\section{Detailed objectives are}

1. Determine if removal of buried waste from below or at grade is more productive

2. Assess (on a subjective basis) the degree to which careful and deliberate operation (e.g., minimizing spillage) contributes to dust suppression and the need for contamination control systems

3. Determine the volume rate of retrieval for different waste orientations. Assess, the average density of the waste/soil matrix

4. Determine the correct suite of end effectors required to efficiently exhume the buried waste and soil

5. Determine how well the technology lends itself to remotization

6. Produce a rough order of magnitude (ROM) estimate for the cost to remotize each piece of equipment used in the demonstration

7. Determine if the use of closed circuit television (CCTV) can enhance and improve operator views of the work area.

\subsubsection{Data Quality}

The data quality objectives establish the precision and accuracy for measurements obtained during the test. All measurements shall be obtained within the accuracy requirements stated in Table 1.

Table 1. Measurement error tolerances.

Measurement Error tolerance

Volume

Mass

Elapsed time

Distance

Illumination-incident

Illumination-reflective

Significance

Dust

$$
\begin{aligned}
& \pm 10 \% \\
& \pm 3 \% \\
& \pm 5 \text { seconds } \\
& \pm 1 \text { in. } \\
& \pm 1 \text { foot-candle } \\
& \pm 1 \text { foot-candle } \\
& P \leq 0.05^{\mathrm{b}} \\
& \mathrm{N} / \mathrm{A}^{\mathrm{c}}
\end{aligned}
$$

a. For each truckload of simulated waste and soil.

b. Statistical validity for inferential purposes.

c. Subjective measure. 


\subsubsection{Basis for Data Quality}

The following is an explanation of how the error tolerances for each of the measured data quality objectives was determined.

- Volume-The $\pm 10 \%$ is based on engineering judgement and experience. Given the heterogeneous nature of the material being measured and the method of measurement being employed, this error tolerance is acceptable.

- Mass-Weighing the soils and debris excavated from the pit within a tolerance of $\pm 3 \%$ is based on the capability of the truck scales that are located at the CAT ETC.

- Elapsed time-This measurement is a judgment call based on what is realistically needed and can be expected when test personnel are timing excavation cycles. Cycles will be timed from the dumping of material into a transport box until the next load of material is dumped. An accuracy of \pm 5 seconds is easily obtainable and is commensurate with the quality of the data being obtained. Most cycles will probably take several minutes to complete, so measuring within 5 seconds is acceptable.

- Distance-A measurement tolerance of \pm 1 in. was based on judgment. Distance measurements will be made for pit construction and to determine excavated volume. Standard tape measures and survey techniques will be used for this activity. Measuring within an inch is easily obtainable and will yield usable results.

- Significance-Based on the test engineer's experience and judgment for this type of field test, the significance $(P \leq 0.05)$ is adequate.

- Incident and reflective illumination-The \pm 1 foot-candle is the practical limit of the instrument measuring the illumination.

- Dust measurements-For the type of work performed, this tolerance is adequate. Dust measurements are strictly subjective and will be made by test personnel who witness the demonstration. The purpose of making the observation is to gain additional information about the effectiveness of using deliberate and careful motions to reduce agitation and subsequent aerosolize of the dust while removing buried waste. The observations will be recorded as follows:

- No visual dust.

- Low dust. The observer is aware that dust is present, but it may be barely noticeable.

- Medium dust. A cloud of dust is generated during the removal process that is thick enough to visually obscure portions of the immediate work area.

- High dust. A dispersion of dust concentrated enough to almost completely or completely impair the vision of personnel observing the test. 
All personnel making entries into the field log book concerning dust concentrations will initially observe the first excavations. They will reach a consensus on what is observed versus how much dust is generated. In this way, a consistent method for gauging the relative dust concentrations will be achieved.

Many hours of video tape will be taken of the demonstration. Much of this taping will include commentary that will be corroborated with the project log. In the future if there are questions about the level of dust generated based on the subjective scale presented above, a review of the tapes could provide this information. 


\section{PROJECT ORGANIZATION}

The general organization and responsibilities for key project personnel are shown in Figure 1. In addition to CAT engineering and operations personnel, Martin Marietta Aero \& Naval Systems (MMA\&NS) will support all phases of T\&E including personnel onsite at the Edwards Training Center during critical periods of preparation, demonstration, and demobilization. Resumes and qualifications for the CAT and Martin Marietta personnel are included in the CAT Project Management Plan. 


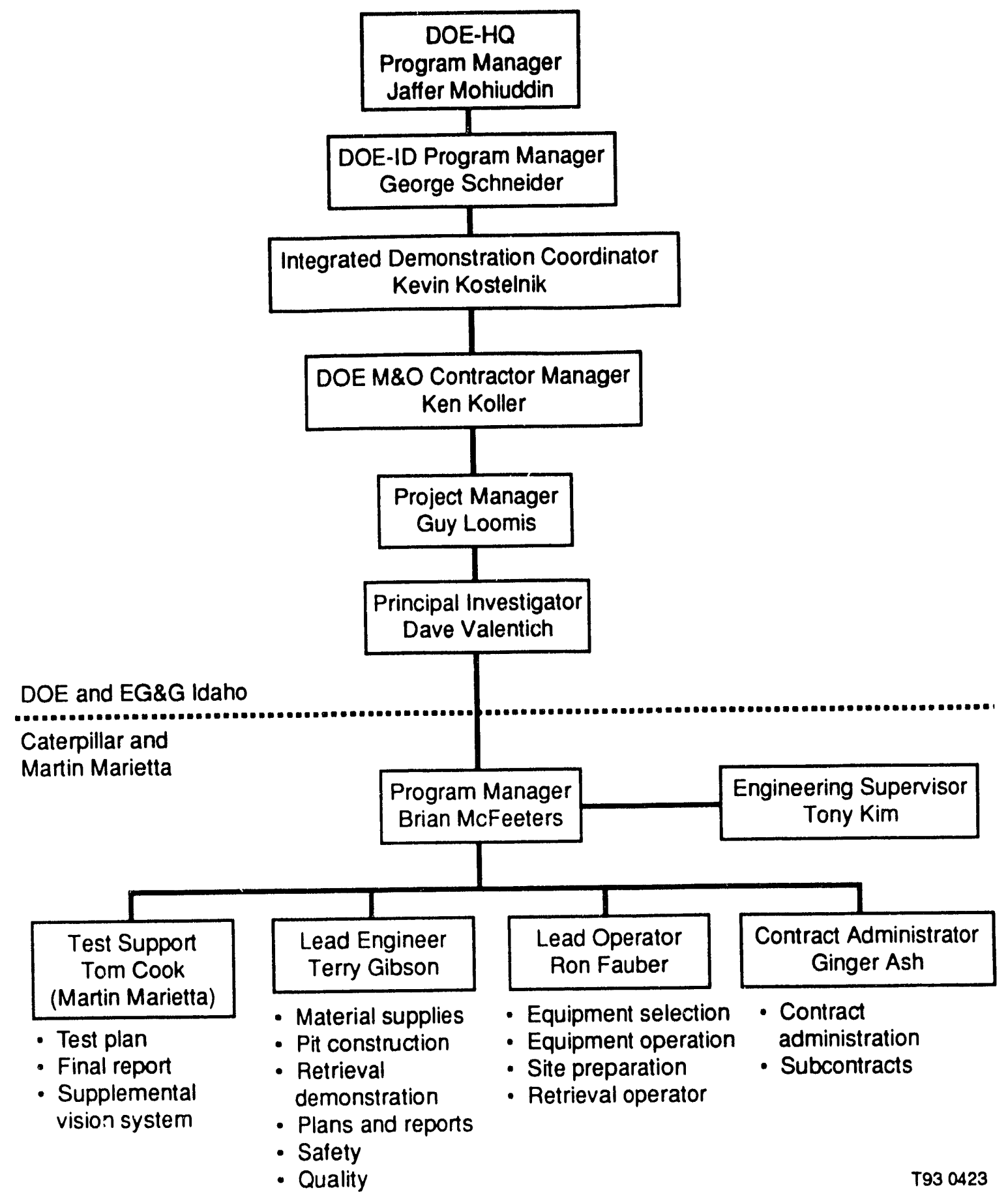

Figure 1. Organizational structure. 


\section{DEMONSTRATION AND EVALUATION PLAN}

This section contains details describing how the demonstration environment will be constructed and how the demonstration will be conducted. Detailed test procedures and protocols are contained in Section 5. During all phases of pit construction and retrieval, a project log book will be maintained and video and still photos taken to preserve pertinent and important aspects of the test. Requirements for the project log video and still photos are

- Project $\log -\mathrm{CAT}$ will be responsible to assign an individual who will control the log and make entries on a daily basis while work is progressing (specific information to be contained in the log is detailed in Section 5.4). Entries shall be neat, legible, and made in ink.

- Video-CAT will assign an individual who shall be responsible for obtaining video footage of the work in progress. As a general guideline, approximately 1 hour of video will be acquired each working day. Whenever possible, anomalous events shall be recorded in their entirety. A video camera will be available at the jobsite ai all times while work is in progress. At the end of every second day of filming, a backup copy of the video will be made. A video log will be maintained on a daily basis that records the time and date, a brief description of what is being recorded, and tape counter indication.

- Still Camera Photos-These may be taken by any project personnel (CAT, MMA\&NS, EG\&G Idaho), provided that the photos are going to be used in support of the project or business purposes. Photos taken for personal or other use are not allowed.

There are numerous resources available within CAT for contingency support. CAT maintains a large fleet of equipment at the ETC that can be used if the primary test equipment fails and cannot be repaired. Peoria, Illinois, is a primary manufacturing and distribution center for spare parts, so there is a high probability that any spare parts will be readily available. The ETC also has a full staff of operators and mechanics who can support the project if the primary personnel are not available. Other resources, such as cold test pit construction materials, support video equipment, and field data collection computer, are obtainable and/or replaceable within a short timeframe. The completed readiness reviews for the cold test pit construction and retrieval demonstration provide a more complete explanation of contingency planning.

\subsection{Cold Test Pit Configuration and Waste Forms}

Details for the location, dimensions, and construction of the pit, composition of waste, placement of waste in containers, placement of containers in the pit, backfilling, and related details are given in Appendix A. "kequirements Verification Matrix."

Configuration of the cold test pit is intended to closely simulate the actual arrangement of boxes, drums, and large objects as contained in buried waste pits and trenches. The construction of this cold test pit is based on historical records and photographs of actual TRU buried waste pits and trenches. 


\subsubsection{Cold Test Pit}

The cold test pit will be constructed at the CAT owned and operated ETC on the Old Power Parade site, which is approximately 1 mile from the ETC offices and maintenance shop. The pit will be $70 \mathrm{ft}$ long $\mathrm{x} 32 \mathrm{ft}$ wide $\mathrm{x} 13 \mathrm{ft}$ deep (after compaction). The pit will be excavated with sufficient slopes to ensure personnel and equipment safety are provided and will be cut $11 \mathrm{ft}$ deep into existing soil. An additional $2 \mathrm{ft}$ of compacted backfill material will be placed over the pit, so the total depth will be $13 \mathrm{ft}$. The pit excavation will be sloped to provide sufficient drainage and reduce the possibility of standing water. Tarps will be placed over the top of the pit to protect the soil from water and keep the pit as dry as possible. Dry soil is desirable because it will more closely simulate conditions expected in an actual pit or trench (at a location such as the INEL or Hanford Site). The dry soil will give a better indication of whether careful excavation and handling of the waste is an effective method to help suppress dust.

The pit will have two large sections $(32 \times 35 \mathrm{ft}$ and $32 \times 25 \mathrm{ft}$ separated by a 10-ft wide soil berm. The area surrounding the pit is free and clear of obstructions and provides sufficient room for safe storage and maneuvering of equipment and vehicles. A plan view of the proposed site is shown in Figure 2.

Pit dimensions will be marked and verified by establishing benchmark elevations before excavation and by setting offset stakes for horizontal location so that the buried waste location is easily located and verified.

\subsubsection{Waste Forms and Placement}

Much of the waste material required for the pit will be provided from local CAT recycling centers and will conform with all applicable Federal, state, and local regulations. Containers (cardboard boxes, cardboard, and metal drums) will conform in size, number, composition, liner material (polyethylene), and consistency to the requirements contained in Appendix A.

Figure 3 shows the plan and elevation for the random dumped boxes and drums and large objects cell. Figure 4 shows the layout and elevation for the stacked boxes and drums cell.

\subsubsection{Cold Test Pit Configuration and Construction}

The guidance presented here will be followed for construction of the test pit site. A hillside site has already been selected for optimal drainage.

1. Prepare the field test site with soil at optimum moisture content for best compaction during the time of the year scheduled for the excavation (April-June). Compact top layer to $>90 \%$ of maximum density.

2. Lay out the test site so that there is sufficient, safe working room for all planned operations.

3. Lay out and clearly mark the pit (completed by CAT site engineers). Take photographs of the layout and a video of the original site conditions. 


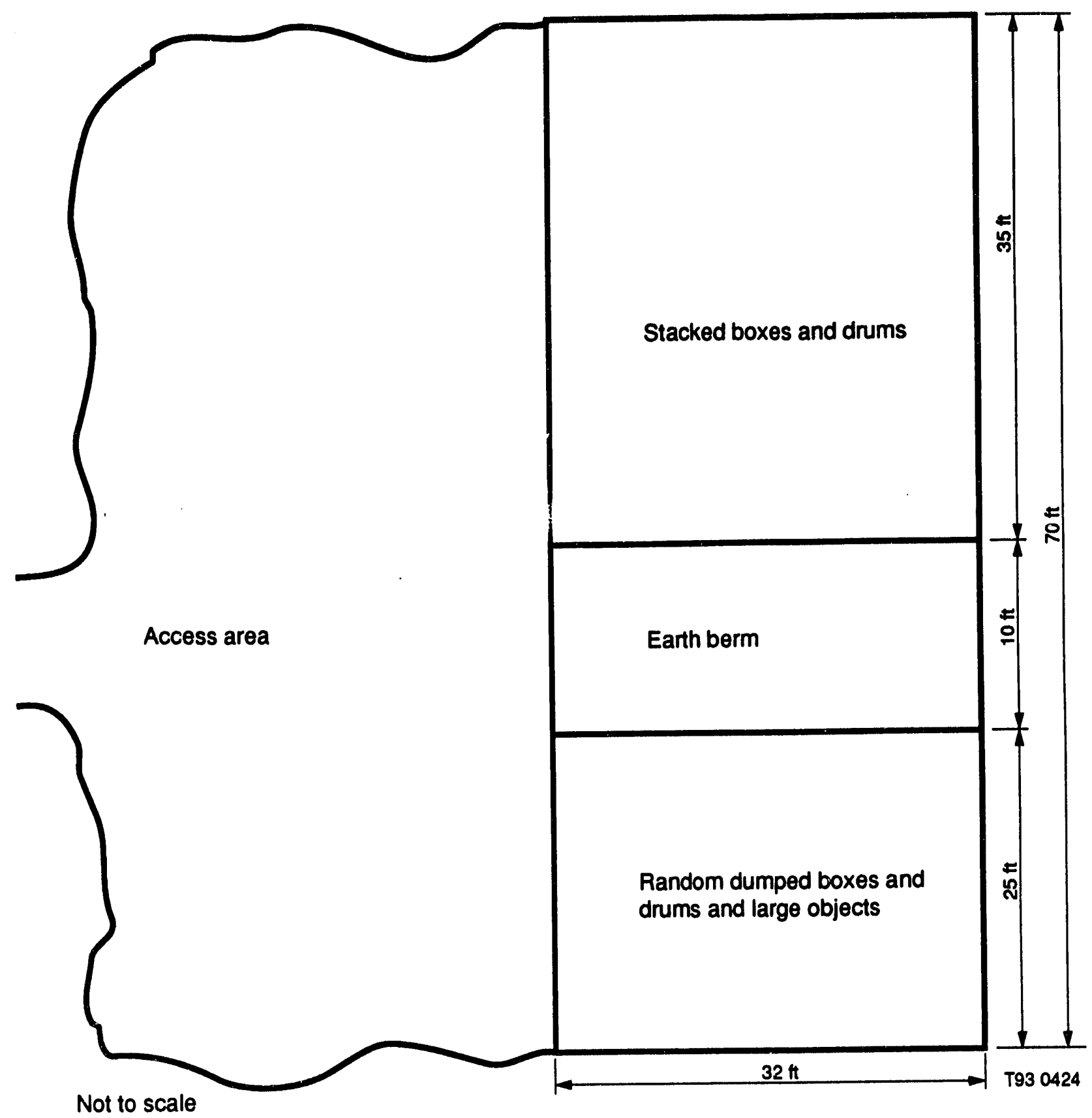

Figure 2. Layout of cold test pit. 


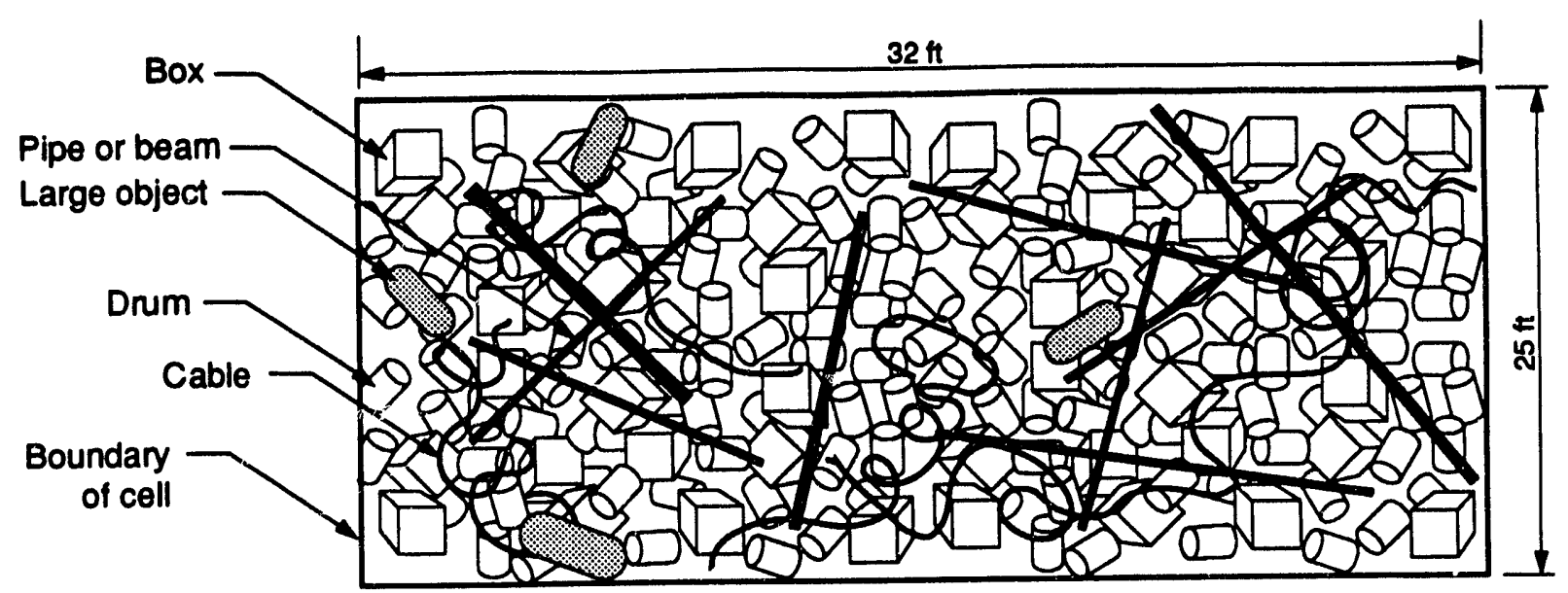

Plan view

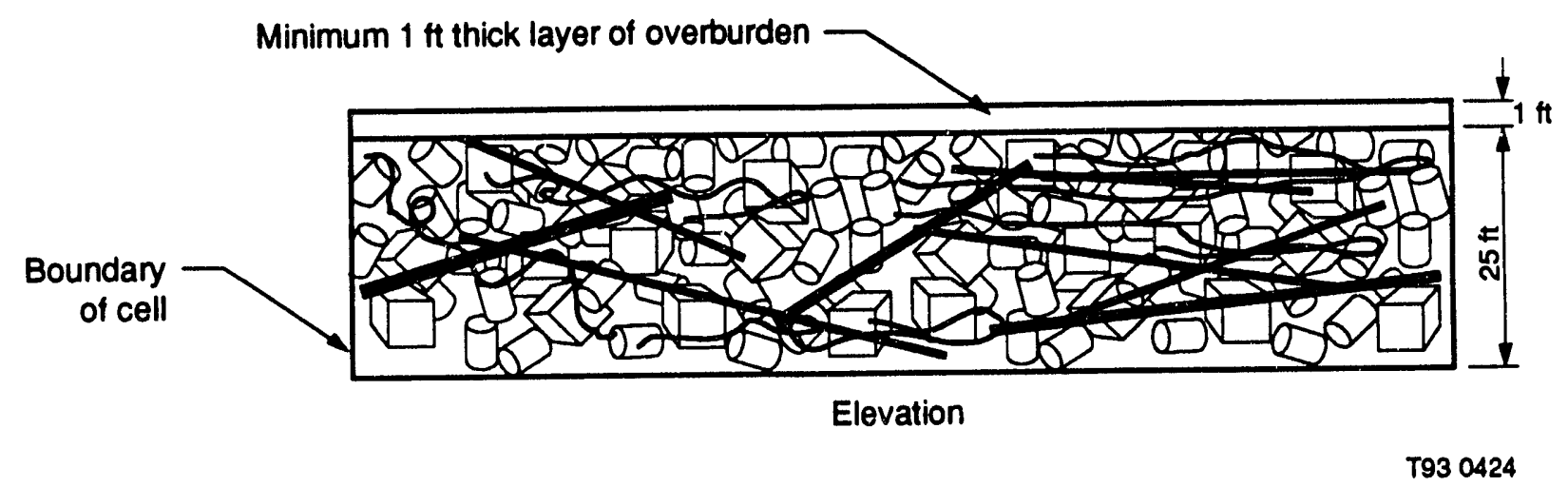

Figure 3. Plan and elevation views of the random dumped boxes and drums and large objects cell. 
Note: Drums are shown for configuration only. A minimum of 220 drums shall be interred in the stacked drums region of the pit. Drums will generally be stacked 2-4 rows high, and the exact arrangement can be determined in the field when pit construction starts.

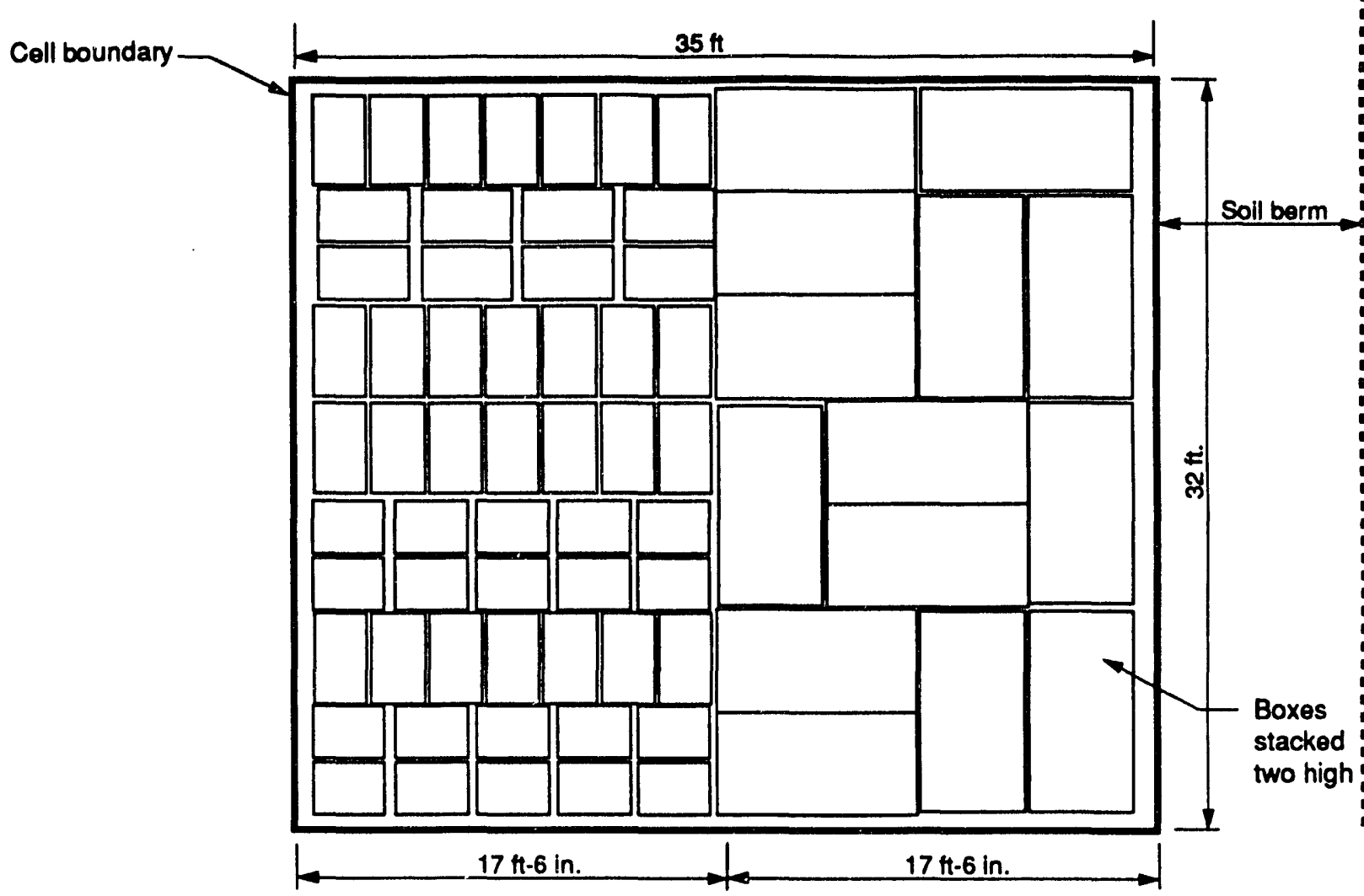

Plan view

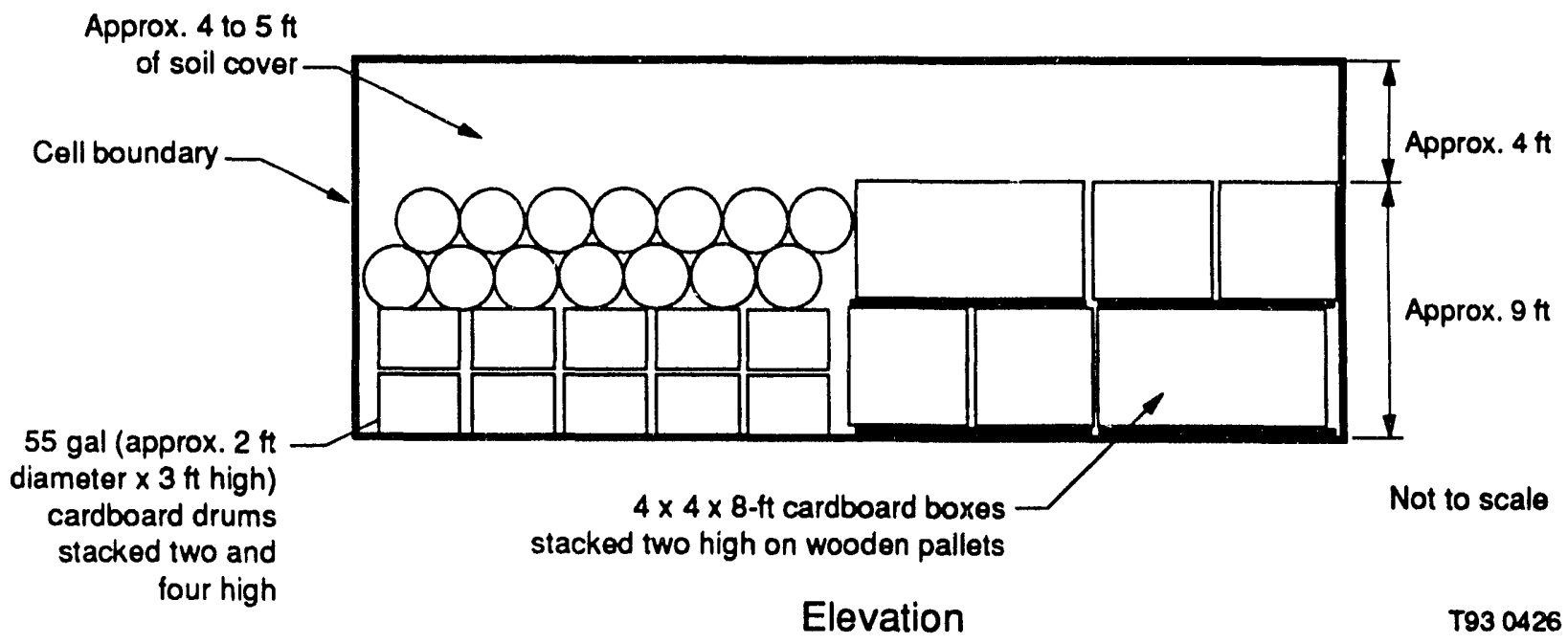

Figure 4. Plan and elevation views of the stacked boxes and drums cell. 
4. As soon as practical after approval to proceed from the contractor, stage and inventory all required waste forms. Once all required materials and equipment are available, start excavation of the pit, beginning with the area designated for stacked boxes and drums. Record video of typical and special excavation activities.

5. Stack cell with boxes and drums and saturate with water. Record video of all significant procedures and events.

6. Excavate cell for random dumped material, leaving a 10-ft wide earth berm in place between the celis. Record video of all significant procedures and events.

7. Fill cell with randor. piaced material and saturate with water. Kecord video of all significant procedures and events.

8. Iristall or adjust offset stakes to accurately reflect inside location and dimensions of the pit. Record this procedure, in ihe project $\log$ and on video.

9. Backtuil both fits and compact to benchmark elevation. Compact to at least $90 \%$ of the maximum density. Fecord ideo of all significant procedures and events and include any weather that could affect the compaction of the pit.

10. Cover the pit area with a waterproof tarp.

11. Begin retrievai excavation when all personnel are briefed and equipment is ready and in place.

\subsection{Excavation and Material Handling Concepts}

There are four environments where a variety of equipment configurations will be evaluated. These are

1. Hydraulic encavator (HEX) belowgrade with stacked boxes and drums in pit

2. HEX belowgrade with random dumped material in pit

3. HEX at grade with stacked boxes and drums in pit

4. HEX at grade with random dumped material in pit

Additionally, the HEX will be used to excavate the solid earth berm separating the two waste cells. For all passes, a CAT $235 \mathrm{HEX}$ with shear and CAT integrated tool carrier (IT28) with an attachment for moving boxes will be available to perform the required cutting and transport operations.

The volume of the cold test pit is $1080 \mathrm{yd}^{3}$ (measured neatline from the pit boundaries). Al! retrieval and removal related work will be completed in 15 working days. Retrieval is scheduled to 
start the first week of June 1993 and continue through the month. An average of $80 \mathrm{yd}^{3} /$ day is the target production rate for removal of the simulated buried waste from the pit.

The pit consists of three sections (see Figure 5) referenced as follows:

1. Section A: Random dumped pit section

2. Section B: $10-\mathrm{ft}$ earth berm

3. Section C: Stacked pit section.

The planned excavation of Sections A through $\mathrm{C}$ will be to make two passes belowgrade and two passes abovegrade (see Figure 5) with each pass 6 to $10 \mathrm{ft}$ wide. A detailed description for each of the four passes follows:

Pass \#1: Belowgrade: Start at Section A, work through B, and stop after completing C.

1. (Re)brief all operators on the objectives of the demonstration and desired standards regarding dust containment, spillage, and safe operation. Emphasize that careful, deliberate removal of the soil and debris is more important than speed.

2. Position the funnel and steel waste containers at convenient positions. All equipment and vehicles will be belowgrade.

3. Use the $325 \mathrm{HEX}$ backhoe with full width Balderson thumb to excavate and place material in the funnel.

4. Set large objects off to the side for the $235 \mathrm{HEX}$ with shear to cut into small pieces for placement in the funnel. The $325 \mathrm{HEX}$ will place the prepared material in the funnel. The $235 \mathrm{HEX}$ will also be used to trim any material (e.g., cable, wire, or pipe) being held by the 325 HEX bucket that would drag on the ground or not fit in the funnel. Objects too large to size will be set off to the side.

Pass \#2: Belowgrade: Start at Section C, work through B, and stop after completing A. This completes belowgrade excavation.

1. (Re)brief all operators on the objectives of the demonstration and desired standards regarding dust containment, spillage, and safe operation. Emphasize that careful, deliberate removal of the soil and debris is more important than speed.

2. Reposition the funnel, steel waste containers, and equipment as required to convenient locations.

3. Use the $325 \mathrm{HEX}$ backhoe with full width Balderson thumb to excavate and place material in the funnel. 


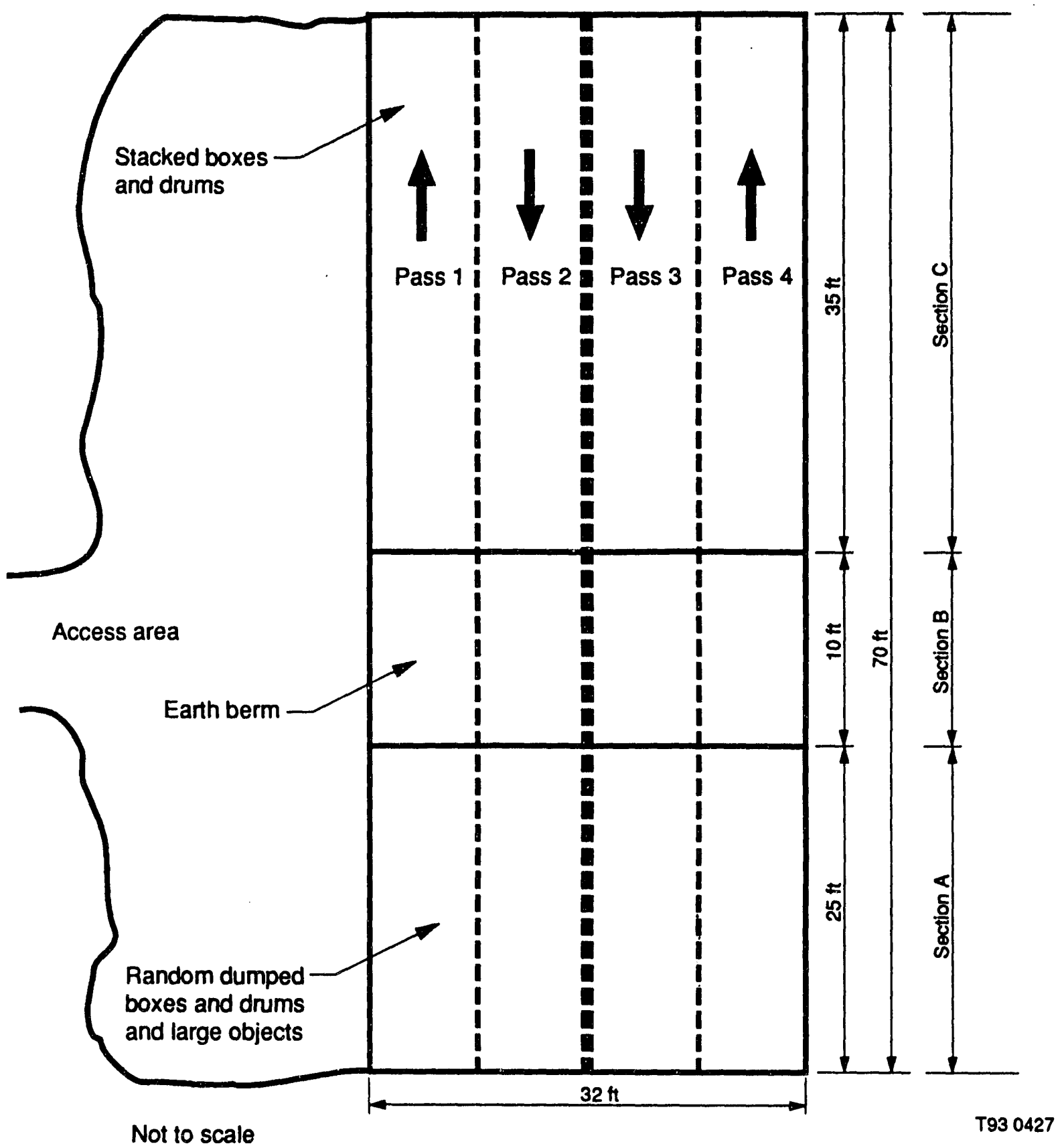

Figure 5. Sections A, B, and C of the cold test pit. 
4. Set large objects off to the side for the $235 \mathrm{HEX}$ with shear to cut into small pieces to place in the funnel. The $325 \mathrm{HEX}$ will place the prepared material in the funnel. The $235 \mathrm{HEX}$ will also be used to trim any material (e.g., cable, wire, or pipe) being held by the 325 HEX bucket that would drag on the ground or not fit in the funnel. Objects too large to size will be set off to the side.

5. Once production rates are achieved, evaluate additional equipment based on discussions between the lead engineer, lead operator, and EG\&G Idaho field representative.

Pass \#3: At Grade: Start at Section C, work through B, and stop after completing A.

1. Rebrief all operators on the objectives of the demonstration and desired standards regarding dust containment, spillage, and safe operation. Emphasize that careful, deliberate removal of the soil and debris is more important than speed.

2. Reposition the funnel, steel waste containers, and IT28 to convenient locations belowgrade.

3. Locate the $325 \mathrm{HEX}$ backhoe with full width Balderson bucket thumb abovegrade and the 235 HEX with shear belowgrade. Provide timber matting to lower ground pressure (maximum $4 \mathrm{psi}$ ) under any equipment operating abovegrade and located within the pit boundary.

4. Set large objects off to the side for the $235 \mathrm{HEX}$ with shear to cut into small pieces to place in the funnel. The $325 \mathrm{HE}$. will place the prepared material in the funnel. The $235 \mathrm{HEX}$ will also be used to trim any material (e.g., cable, wire, or rine) being held by the 325 HEX bucket that would drag on the ground or not fit in the nel. Objects too large to size will be set off to the side.

Pass \#4: At Grade: Start at Section A, work through B, and stop after completing C. This completes at grade excavation.

1. Rebrief all operators on the objectives of the demonstration and desired standards regarding dust containment, spillage, and safe operation. Emphasize that careful, deliberate removal of the soil and debris is more important than speed.

2. Reposition the funnel, steel waste containers, and equipment as required to convenient locations abovegrade.

3. Keep the $325 \mathrm{HEX}$ backhoe with full width Balderson bucket thumb at abovegrade and relocate the $235 \mathrm{HEX}$ with shear and IT28 to abovegrade. Provide timber matting to lower ground pressure under any equipment operating within the pit boundary.

4. Set large objects off to the side for the $235 \mathrm{HEX}$ with shear to cut into small pieces to place in the funnel. The $325 \mathrm{HEX}$ will place the prepared material in the funnel. The $235 \mathrm{HEX}$ will also be used to trim any material (e.g., cable, wire, or pipe) being held by 
the 325 HEX bucket that would drag on the ground or not fit in the funnel. Objects too large to size will be set off to the side.

The reason that above and belowgrars excavation will be performed is to resolve a long standing issue about productivity. Half of the pit will be excavated from belowgrade and half from abovegrade. Production rates, ease of operation, and operator comfort will be monitored to help determine which position is more favorable. The concept of four separate passes has been incorporated into the test so a variety of different waste configurations of the type that could be encountered in an actual buried waste pit will be simulated.

\subsection{Operator Augmentation Concepts (Camera, Displays, etc.)}

A critical step in determining the degree to which typical excavation and material handling equipment can be effectively remotized for buried waste tasks is determining what information is essential for a remote operator. Toward this goal, remote camera configurations, with both mono and stereo and color and black and white that are aboard the prime equipment will be incorporated into the test to facilitate visibility of the dig face to the operator and to determine what configurations provide the best information.

Martin Marietta's on-going Independent Research and Development Program has confirmed that vision requirements and control fidelity are the overriding considerations for successful teleoperation of large equipment or vehicles. Operators must be provided with a minimal set of depth, distance, and "relations" cues depending upon the nature of the task. Issues related to visual display resolution, camera type and location, lighting, and display position(s) and a variety of sensory perturbations can have dramatic effects on operator performance and endurance.

It is intended to have a variety of visual feedback options onsite during the retrieval demonstration. Each of these systems will be used to help evaluate issues such as the effects of stereo vision and camera placement on task performance on a "not to interfere" basis. Data gathered from this work will make a significant contribution to the further understanding of remote vehicle requirements for large excavators intended for DOE waste retrieval efforts.

Future details on the camera evaluation studies (including technical details of hardware that will be used in the field and the specific method for obtaining data to perform the evaluation) will be presented before the retrieval readiness review. Summary level results of the onsite evaluations will be included as part of the final report. Complete field installation, testing, and checking of the systems to be used will be accomplished before the start of the retrieval demonstration.

\subsection{Remotizing Issues and Options}

The daily log will include specific references and observations appropriate to remote options for various phases of the excavation and material handling process. Results of these observations and specific recommendations relative to the equipment evaluated and "essential information" identified from the video camera studies will be summarized in the final report. 


\section{DEMONSTRATION PROCEDURES}

Additional procedures for the demonstrations and evaluations described in Section 4 are given in this section.

\subsection{Site Preparation}

1. Before starting the retrieval demonstration, remove material to access belowgrade area shown in Figure 2. This material will be relocated and the volume not included as part of the total pit volume. Time taken for removal of this material will be recorded in the field $\log$ but not included in demonstration statistics.

2. When the access area has been prepared, photographs will be taken of the site configuration, and all deviations will be recorded in the field log.

3. Waterproof tarps will be located onsite to cover the cold test pit in the event of rain. Daily rainfall and any apparent impact on the cold test pit will be recorded in the field log and on video tape as appropriate to document the conditions.

4. Funnels and waste containers will be inspected, pretested, and staged before the demonstration.

5. Equipment to be used in the demonstration will receive a thorough technical inspection and have all scheduled and required maintenance performed before start of the demonstration. A field log entry will be made to describe any discrepancies and EG\&G Idaho approved waivers.

6. Previously established offset stakes (pit and cell boundaries) will be verified, and stakes/tape to indicate simulated containment building boundaries will be clearly marked and in fuli view of the operator. The imaginary boundaries will be located $10 \mathrm{ft}$ beyond the short sides $(32 \mathrm{ft}$ ) of the cold test pit and $10 \mathrm{ft}$ beyond the expected maximum position of the excavators from the abovegrade position on the long side $(70 \mathrm{ft})$ of the pit. The imaginary containment building boundaries will be observed, and an attempt to perform all retrieval operations within these boundaries will be made. If after a reasonable time, it is apparent that the excavation cannot be performed within the boundaries of the imaginary building, the excavation will proceed and an explanation included in the field log about why the boundaries could not be honored.

\subsection{Dig Face Removal and Sizing Methods}

It is expected that several methods will be tried to remove debris from the dig face and to size, handle, and remove the materials. First, if the thumb and bucket attachment on the HEX 325 can grasp an entire load of, for example, steel, and pieces are bridged between the bucket and dig face, the shears will be used to trim the excess material. If the HEX 325 encounters a beam, pipe, or other large object that must be sized, there are several methods that may be employed. The HEX 325 may drag the object out from the dig face and place it off to the side where the shears will 
cut the object into manageable pieces to place in the transport box. If a sizable portion of the object is exposed and protruding from the dig face, the HEX 235 with shears may try to size the item in place without the aid of the HEX 325. Another approach might be to have a stockpile of items to be sized that would be fed from the HEX 325 and continuously worked by the shearing unit. All of the options described and others may be tried depending on how well material is removed from the dig face, sized, and placed in the storage boxes.

The IT28 may cross the imaginary building boundaries to transport boxes. Only retrieval related activities performed by the excavators and related equipment will be conducted within the imaginary building boundaries.

\subsection{Precautions}

The following precautions will be observed throughout the conduct of the retrieval demonstration. Any variances will be approved by EG\&G Idaho and recorded in the field log.

1. Work beyond the authorized scope of the project will not be performed without approval of the project manager. The lead engineer will review all daily activities before commencing work to ensure compliance with the scope of work.

2. Before starting excavation, no containers or objects may protrude above the waste seam.

3. Particular care will be taken to minimize waste and soil spills and dust generation throughout all phases of operation.

4. Particular care will be taken not to exert over 4 psi pressure on the work area during abovegrade operations or to work too close to the leading edge of the excavation to cause ground failure and injury/loss of equipment.

5. During periods of inclement weather and/or strong winds, onsite personnel will exercise caution and cease field operations when conditions could compromise safety.

6. Direct human contact with the waste to help position equipment and end effectors is not permitted.

7. Excavated waste must not excessively protrude from the bucket or drag on the ground during transport, and spillage must be minimized. Material placed in the storage box must not be spilled outside of the box during placement or excessively protrude from the box.

8. Selected equipment will not cause undue congestion of movement during the demonstration. 


\subsection{Demonstration Operations and Evaluation Objectives}

All operations associated with the retrieval demonstration are designed to assess the ability of the chosen suite of C.AT equipment to exhume buried waste in defined forms. The sequence of operations for the demonstration are described in Section 4.2.

The following evaluation objectives will guide the conduct of the demonstration:

1. Characterize the performance of known equipment configurations for specific tasks over each cycle (see Section 5.5). Each cycle constitutes a data "case," and sufficient data from all cases will be recorded. All trials will be recorded to ensure validity of statistical analyses and conclusions. One complete cycle will be considered from the time material is placed in the funnel until the next load is placed in the funnel.

2. Assess the feasibility and ROM estimated costs to remotize each equipment configuration for future cold test pit demonstrations. Report conclusions and recommendations in the final report.

If at any time during the retrieval demonstration, it is judged br the EG\&G Idaho field representative that the primary selected equipment and end effectors dre not making required production quotas, the representative may direct that other equipment and end effector configurations be tried to determine if the exhumation rate can be improved.

\subsection{Dependent Measures}

The following variables represent the primary evaluation issues associated with the demonstration. Data gathering and recording wii! focus on these variables, and subjective analyses from the field will be combined with empirical data to form a descriptive picture of equipment/configuration performance. In addition, summary statistics will be maintained to reflect total production for the day in terms of waste container loads, types at the percent full, large object set aside, and all unplanned operations and actions such as tabulating any down time or conditions that call for the equipment operator to leave the cab.

A minimum of 4 cycles/hour per section will have the dependent measures as outlined below recorded. Additionally, anomalous conditions or other conditions as determined by the lead engineer will have the associated dependent measures recorded. A count of the total cycles will be maintained in the project log book. The cycle count will be distinguished by the pass and the section of the colr? test pit.

1. Configuration Capability-Defined as the ability of a specific equipment configuration to excavate, handle, and place specified waste forms and mixes. Capability is measured in terms of

a. Task Completion (a categorical variable: complete/incomplete). In the event that a specific equipment configuration is unable to complete a cycle for a certain waste form or mixture, detailed descriptions of the problems encountered will be made in 
the field notebook and a pictorial record kept via stills and video as appropriate. Operator input is especially significant in such cases and will be recorded. It is important to know what doesn't work and why. Timely and accurate records will be m: ‘tained.

b. Cycle Time (a continuous variable: minutes, seconds). A cycle is measured from the time a load of soil and debris is dumped in the funnel until the next load is dumped in the funnel.

c. Percent Utilization of Bucket Capacity. A categorical variable based on direct observation of contents:

$0 \%-25 \%$

$26 \%-50 \%$

$51 \%-75 \%$

$76 \%-100 \%$

Note: A bucket that is $100 \%$ full would contain approximately $1 \mathrm{yd}^{3}$ of material.

d. Dust Generation (an ordinal variable: no visible dust, low-medium-high dust). Dust generation is based on direct observation of conditions by trained test personnel. This is a subjective observation, and the findings will be qualified as such in the final report.

If a configuration is not able to complete a cycle, it will be noted as incomplete and a detailed description recorded in the project log. Possible remedial actions/solutions will also be recorded.

This is the initial set of measures of effectiveness (MOE's). As additional performance measures are identified before the demonstration, they will be documented on an on-going basis for implementation and entered into the test plan at a later date.

\subsection{Independent Measures}

1. Demonstration condition includes one of four major types of waste forms (a categorical variable).
a. Belowgrade, stacked barrels and drums
b. Belowgrade, random dumped material
c. At grade, stacked barrels and drums
d. Al grade, random dumped material 
2. Equipment configuration (a categorical variable) with "to be determined" categories.
a. Primary excavator (type/model)
b. Attachment (type/model)
c. Support equipment (type/model)
d. Other (describe)

3. Environmental conditions (an ordinal variable describing prevailing weather and visibility conditions).
a. Sunlight intensity
b. Cloud cover (clear, mostly clear, mostly cloudy, overcast)
c. Shadows (sharp, fuzzy, none)
d. Wind (light, moderate, heavy)
e. Rain (drizzle, steady, heavy, none)
f. Estimate of temperature and humidity

4. Operator number (assign each operator an identifier).

5. Time of day: 24 hour clock

6. Contents of discrete load includes a categorical variable describing the contents of the bucket load.
a. Dirt only
b. Dirt mixed with small debris
c. Dirt mixed with large debris
d. Mixed waste not requiring additional processing from the shear
e. Mixed waste requiring additional processing from the shear
f. Steel form not requiring processing
g. Steel form requiring processing 

h. Large objects set aside (e.g., steel tank, machine tools)
i. Other mixtures of interest (to be determined)

7. Operator input (obtained at least daily from each operator).
a. Machine operability
b. Operator comfort
c. Pertinent characteristics of buried wastes
d. On-going lessons learned
e. Improvements or changes that could be made to help productivity

\subsection{Data Management and Analysis}

Data collected during the demonstration period will be recorded on test data sheets (part of the project $\log$ ) and transferred to a computer on a daily basis. A review of the proposed method for data entry and a sample of the test data sheets and project log will be made during the readiness review, which is held before the start of the retrieval demonstration. The primary data reduction and statistical analysis package to be used is StatView, Version 4.01d1 (Abacus Concepts, 1992) that will reside on a MAC PC. Data entry into the PC will be made by qualified personnel. This package will provide quick look data summaries as well as descriptive and inferential analyses in support of the final report. Appropriate data summary tables and charts and cross-tabulation, correlation, analysis of variance, and linear regression techniques will be employed to characterize relationships among the variables of interest (Cook and Campbell, 1979). Once the variables/data are collected, the summary and statistical analyses and reporting formats will be developed as a cooperative effort between CAT, MMA\&NS, and EG\&G Idaho. Examples of the types of analyses that wili he generated from this effort and included as a part of the final report are

- Graphs depicting volume of material retrieved per unit of time (per hour, day, entire test)

- Discussion of which end effectors and equipment were most effective based on performance

- Determination concerning which position (above or belowgrade) was most productive for retrieval of simulated buried waste

- Average time required to complete an entire retrieval cycle (for each type of waste, from above or belowgrade position)

- Comparison of efficiency at start of retrieval versus later (i.e., improvement from learning)

- Graphs and charts examining number of cycles, cycle times, and contents of discrete load 
- Number of loads requiring trimming with shears

- Number of loads where spillage or dragging occurred.

Additionally, collected data will be managed for configuration, will be backed up daily (copied onto a floppy disk or hard drive), and copies of all raw and summary data will be provided to EG\&G Idaho at the conclusion of the project. Upon request, the latest raw data collected to date will be provided to EG\&G Idaho. 


\section{EQUIPMENT}

\subsection{Excavation and Material Handling Equipment}

The following equipment will be employed during the demonstration.

1. Primary excavation vehicle: CAT 325 HEX backhoe configuration with bucket and full-width Balderson bucket thumb

2. Special purpose vehicle: CAT 235 HEX with shear

3. Box mover: CAT IT28 material handler

4. Alternate equipment

a. IT28 with claw

b. CAT $330 \mathrm{HEX}$ with bucket reversed to simulate front shovel configuration

c. CAT 935 track loader with multipurpose clamping bucket.

The above equipment was selected by CAT engineers and operators. After evaluating how the cold test pit was to be excavated, the pit's contents, and available equipment, the above items were determined to be the most likely to contribute to a successful demonstration.

\subsection{Support Equipment and Facilities}

The following support equipment and facilities are located onsite at the ETC. There are no other equipment support requirements for this demonstration. Video equipment will be leased from a local supplier who will be available for repair and replacement. A backup video system will always be on hand.

1. The ETC has a complete maintenance and repair facility with full-time mechanics prepared to support all of the equipment used in the demonstration. In addition, all tools required for field repair are readily available (e.g.., crane, portable welders, air compressors, and air tools).

2. A mobile fuel truck and fixed fuel station are available onsite for vehicle refueling.

3. An 8000 gal water wagon will be used to saturate the simulated waste.

4. Offices with telephones, conference rooms, and a lunch room are available at the ETC during the demonstration period.

5. Support trucks with communication radios are available for moving people, parts, and tools at ETC. A radio will be available onsite at all times for emergencies. 
6. Dozers, loaders, motor graders, compactors, and trucks for preparing the field site, backfilling, compacting, moving, and loading simulated waste on trucks are available at ETC.

7. All equipment necessary for surveying, staking out, and marking the pit and associated boundaries and measurement are available at ETC.

8. Truck scales for measuring removed material are available at ETC.

\subsection{Maintenance, Operation, and Calibration of Equipment}

In addition to normally scheduled preventative maintenance, daily checks and walkarounds will be performed by the operators before starting work and at the end of the work day. Problems noticed will be immediately reported, recorded, and corrected by personnel.

All equipment operations will be in accordance with CAT standard procedures, and all operators will be qualified for the equipment they will operate.

Currently, it is planned that the truck scale will be the only test equipment requiring calibration. The truck scales will be calibrated $( \pm 3 \%)$ before commencing the demonstration. 


\section{QUALITY ASSURANCE}

All test personnel shall strictly adhere to the provisions of the approved Quality Plan. (This document was prepared by CAT and reviewed and approved by an EG\&G Idaho certified quality engineer.) The lead engineer is responsible for supervising all activities to ensure that the work is done correctly. All deviations will be correted immediately and recorded in the field log.

The lead engineer will be onsite during all retrieval demonstration activities and will be the focal point for all decisions. Personnel tasked with volume measurements will be trained by the lead engineer to ensure consistency and are the only authorized personnel to collect such data. 


\section{SAFETY}

All test personnel shall strictly adhere to the provisions of the approved Environmental, Safety, and Health (ES\&H) Plan. (This document was prepared by CAT and reviewed and approved by an EG\&G Idaho certified safety engineer.) The lead engineer is responsible for site safety and with the lead operator will instruct all involved personnel (including observers) before any field work on safety guidelines and emergency actions. All personnel will be advised to report to the lead engineer or lead operator any unsafe practices or conditions observed. Corrective action will be taken immediately. Safety meetings will be held at the discretion of the lead engineer. In addition to the lead engineer and lead operator sharing site safety responsibilities, the ETC has a full time safety officer who will also maintain oversight of the project.

Operators will review the ES\&H plan and related safety manuals and will be trained in the safe operation of their equipment. 


\section{LOGISTICS}

All critical personnel, equipment, supplies, and spare parts necessary for continuous test operations will be located at the ETC. Noncritical backup equipment will be available within 24 hours. Other services required to support the work such as subcontracting, computer facilities, and support personnel are available through CAT.

The logistics support concept will be outlined in detail at the scheduled readiness reviews for cold test pit construction and the retrieval demonstration. All action items resulting from the readiness review shall be closed or waived by EG\&G Idaho before starting associated field work. 


\section{RISK MANAGEMENT}

The project manager and lead engineer are responsible for isolating potential risks that could impact the demonstration. Potential risks will be identified on an on-going basis and proposed mitigative actions taken throughout the life of the project. 


\section{OTHER ACTIVITIES}

\subsection{Measurement of Excavated Quantities}

A measurement will be taken daily to determine how many cubic yards of material were removed from the cold test pit. The void left in the pit from the removed material shall be the basis for making this measurement. Physical measurement of the void will be made with a tape, level, and rod. Each day, the total void of the pit will be measured. The previous day's total will be subtracted from this number to determine how much additional material has been removed during the day. It will be necessary to establish stringlines defining the exact pit boundaries so volumes from side slopes are not included in the void calculations. All measurement activities will be entered into the project $\log$ on a daily basis. Equipment required to make the necessary measurements is available from the ETC.

\subsection{Weighing of Excavated Pit Debris}

At the conclusion of the project as material is removed from the ETC, the trucks hauling the soil and debris will be weighed. A running total of the truck loads will be maintained, and a total weight of the soil and debris placed in the cold test pit will be determined. The trucks will be weighed on a set of scales located at the ETC. A person will be designated as responsible to enter the weight of each load of soil and debris into the project log. No loading will commence until it is verified that the individual responsible for recording the weights is present and ready. All personnel associated with loading, weighing, and transporting the debris will be briefed about the requirements for weight before starting removal of debris from the site. The weighing process will determine a total weight of the material removed from the pit. This information will be helpful in determining future throughput estimates of removal and treatment of buried waste.

As material is initially removed from the pit, it will be stored in three separate piles. Each pile will correspond to one of the pit cells (stacked drums and boxes, separation berm, and random dumped drums and boxes). A separate weight for each pile shall be determined. The weighing will be performed so that materials from each pile are kept separate and not commingled.

\subsection{Disposal of Simulated Buried Waste}

CAT has contracted with a local recycling/hauling company to dispose of the material. Some material may be recycled, otherwise it will be taken to a municipal landfill. Additional details on the disposal of this material are contained in the ES\&H project plan.

\subsection{Document Control}

This test plan is controlled for configuration under EG\&G Idaho guidelines. (This document is issued as an informal report, and the configuration cannot be altered unless strict procedures for doing so are followed.) A redline copy of this test plan will be maintained by the EG\&G Idaho principal investigator. The redlined copy will be marked "Master Copy," and any changes or deviations to the field test will be noted in the copy. These changes will be formally reported in the project's final report. 


\section{BIBLIOGRAPHY}

Abacus Concepts, Inc. StatView, Version 4.01d1, Berkeley, California, 1992.

Balderson Excavator Bucket Thumbs (Form B3290), December 1989.

Caterpillar, Inc., CAT 325, 325L Excavator Brochure, AEHQ2618-02, November 1992.

Caterpillar, Inc., CAT 235D, 235D LC Excavator Brochure, AEHQ2632, July 1992.

Caterpillar, Inc., CAT Integrated Toolcarriers-IT18B/IT28B Brochure, AEDH1928.

Caterpillar, Inc, CAT 330 Excavator Brochure.

Caterpillar, Inc., CAT 935C Loader Brochure, AEDC8099.

Caterpillar, Inc. "Proposal for the Retrieval Demonstration."

Cook, T.D. and Campbell, D.T., Quasi-Experimentation: Design \& Analysis Issues for Field Settings; Rand McNally College Publishing Company, Chicago, Illinois, 1979.

EG\&G Idaho, Inc. "Statement of Work for the Retrieval Demonstration," Subcontract No. C93170232. 
Appendix A

\section{Requirements Verification Matrix \\ Retrieval Demonstration}


A-2 


\section{Appendix A}

\section{Requirements Verification Matrix Retrieval Demonstration}

Table A-1 serves as a checklist to ensure that the requirements as originally noted in subcontract No. C93170232, "Statement of Work" are met. Initially, this table will be used for planning purposes. As the program progresses and actual work is performed, the table will be used to confirm that tasks are completed. A completed copy of this matrix will be included in the project final report. Figures from the text are referenced in this table. 


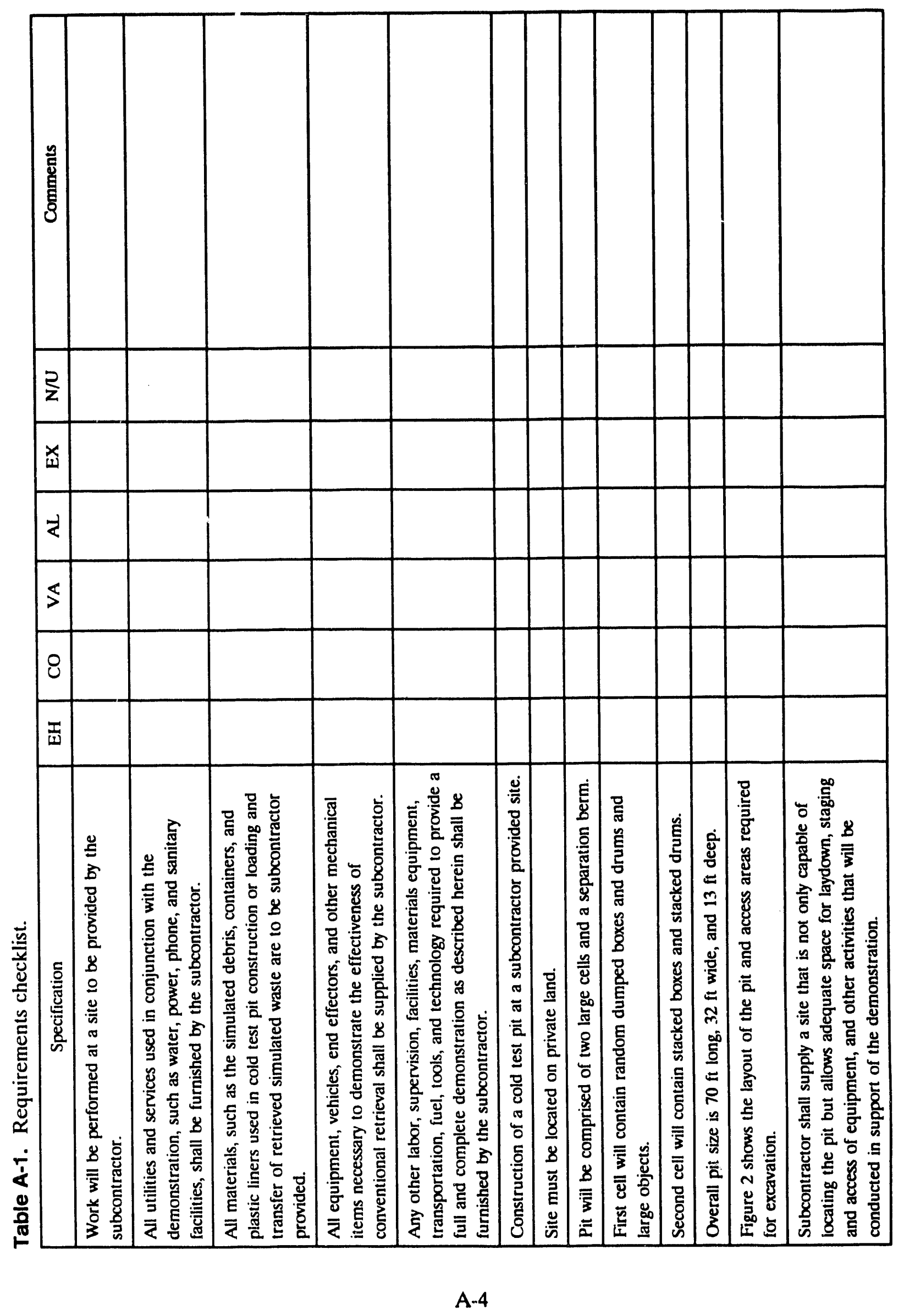




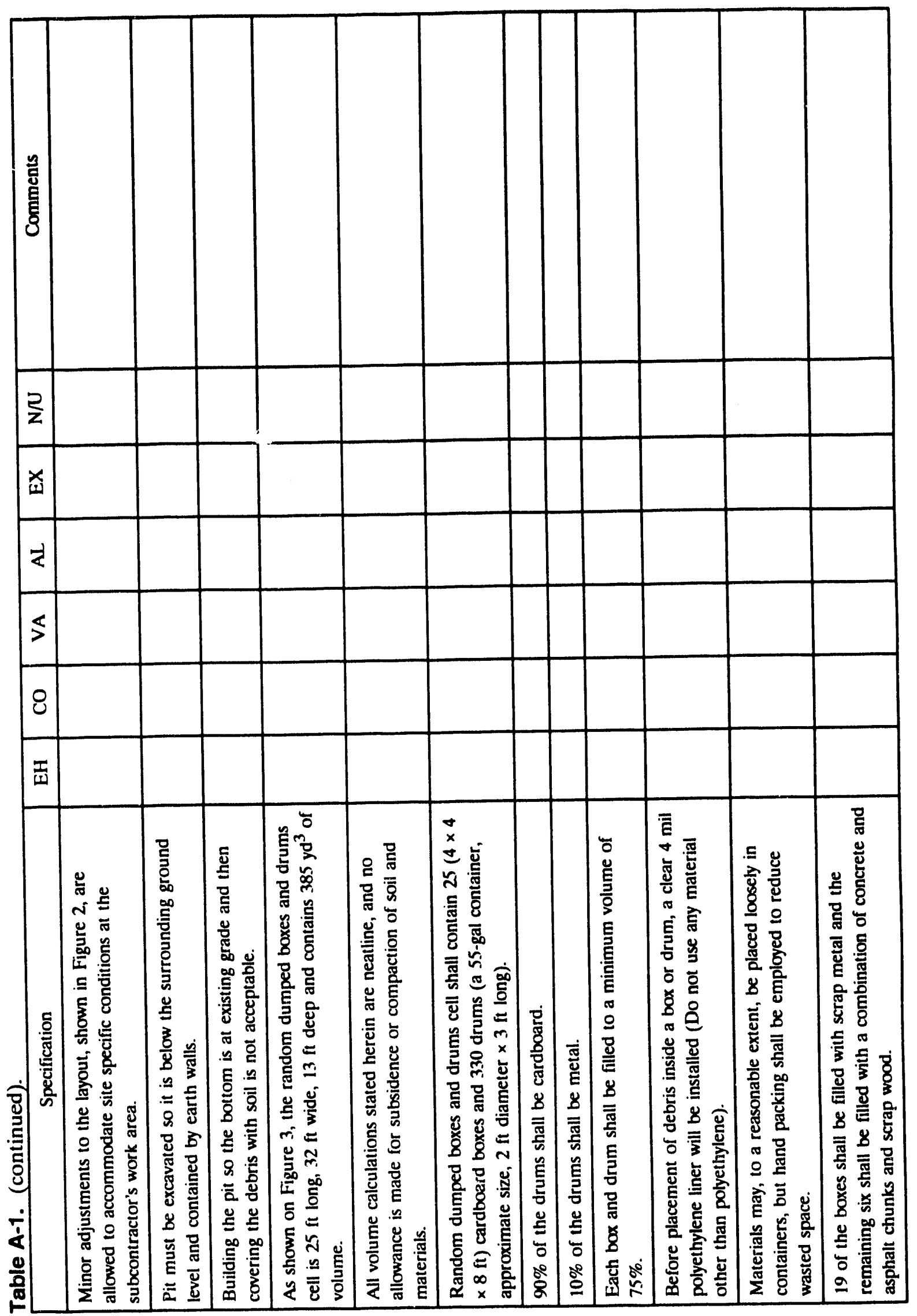




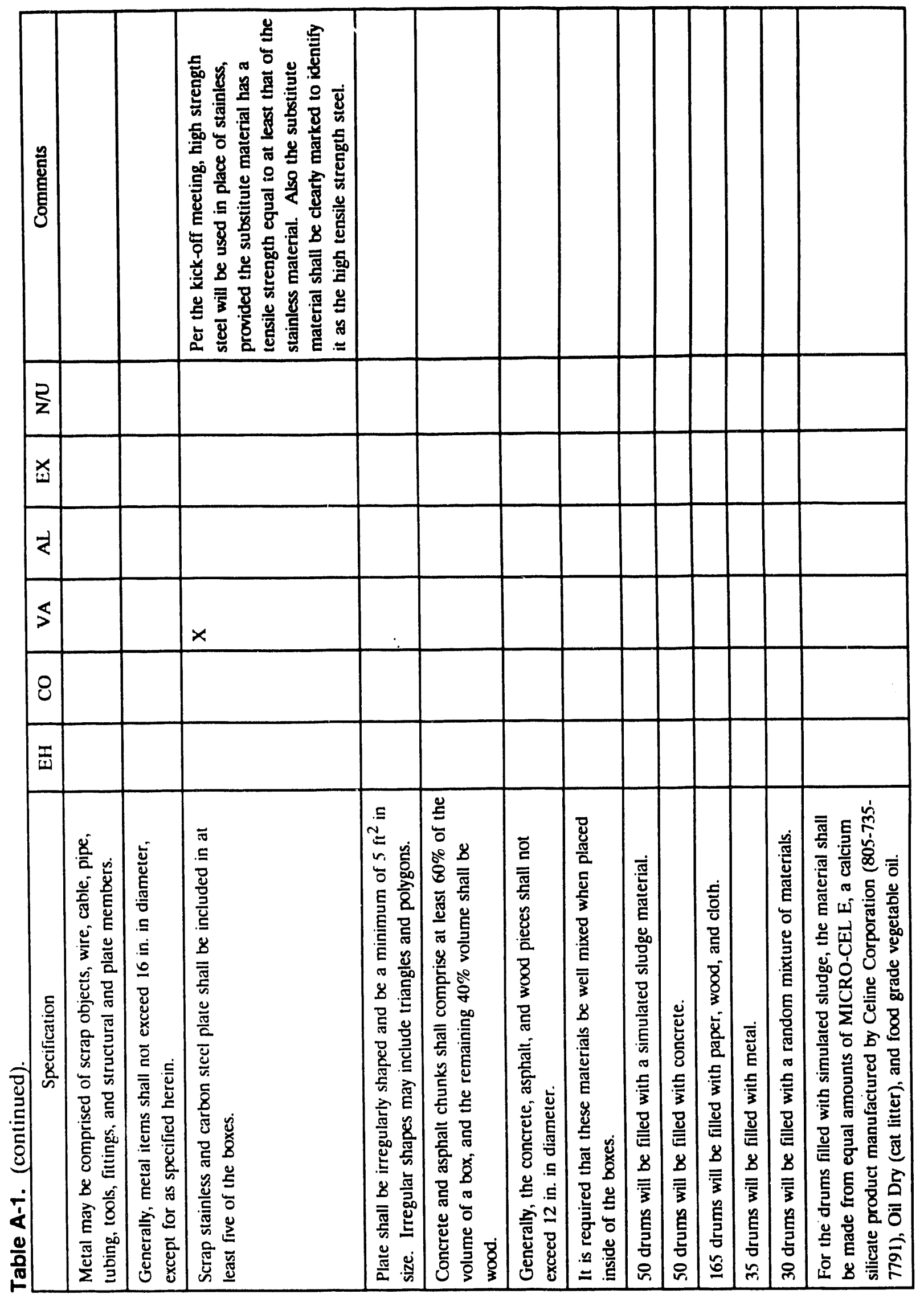




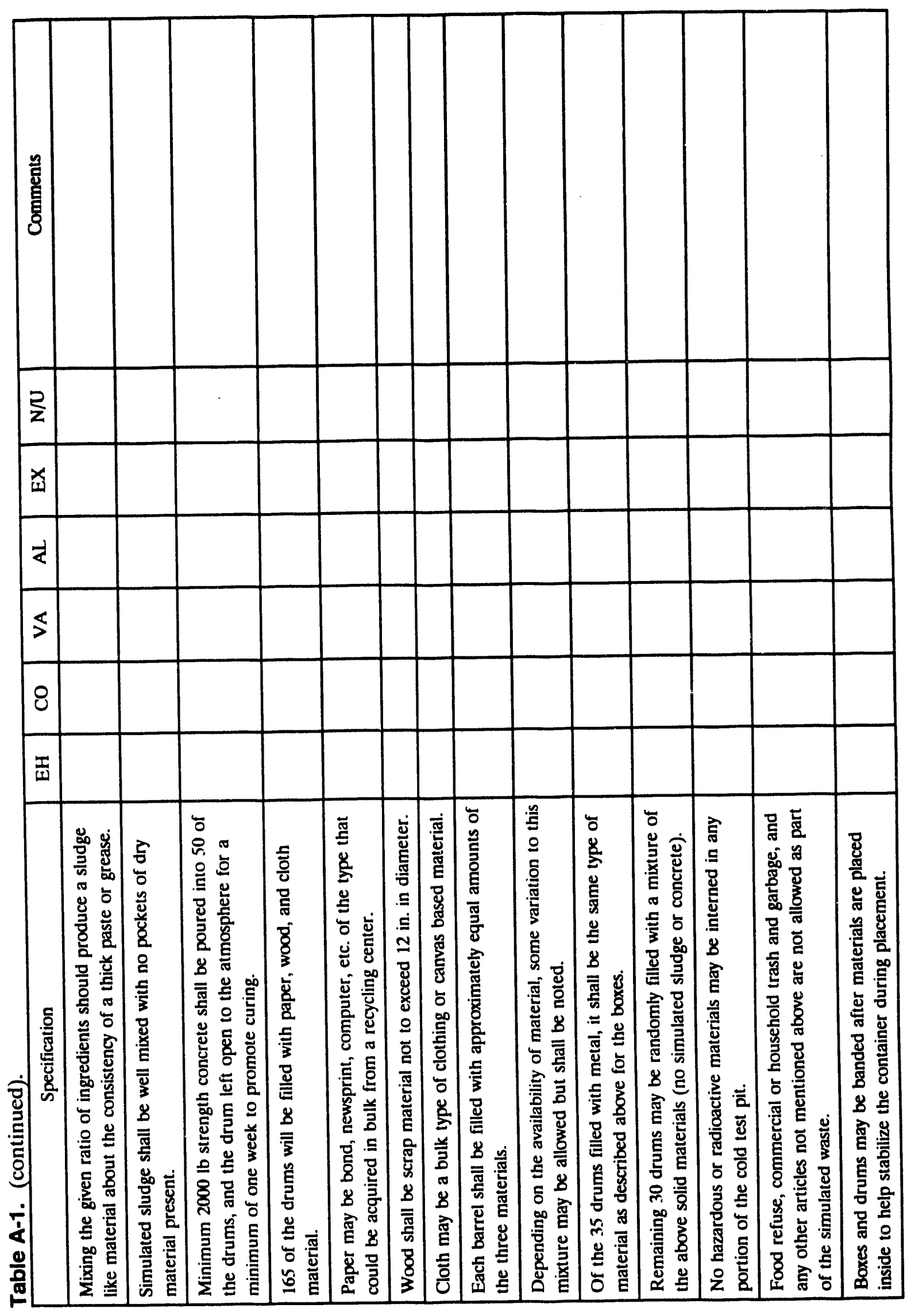




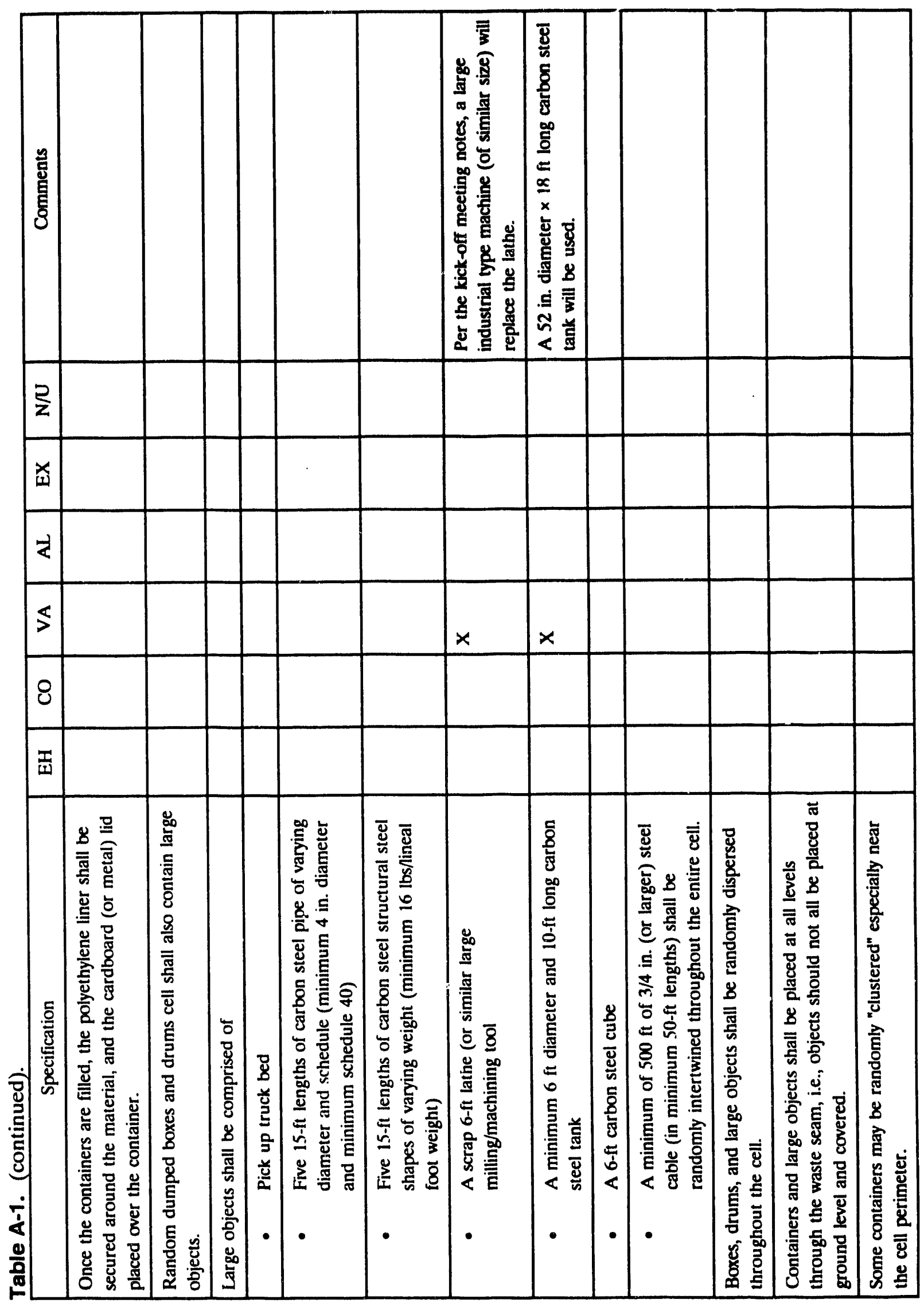




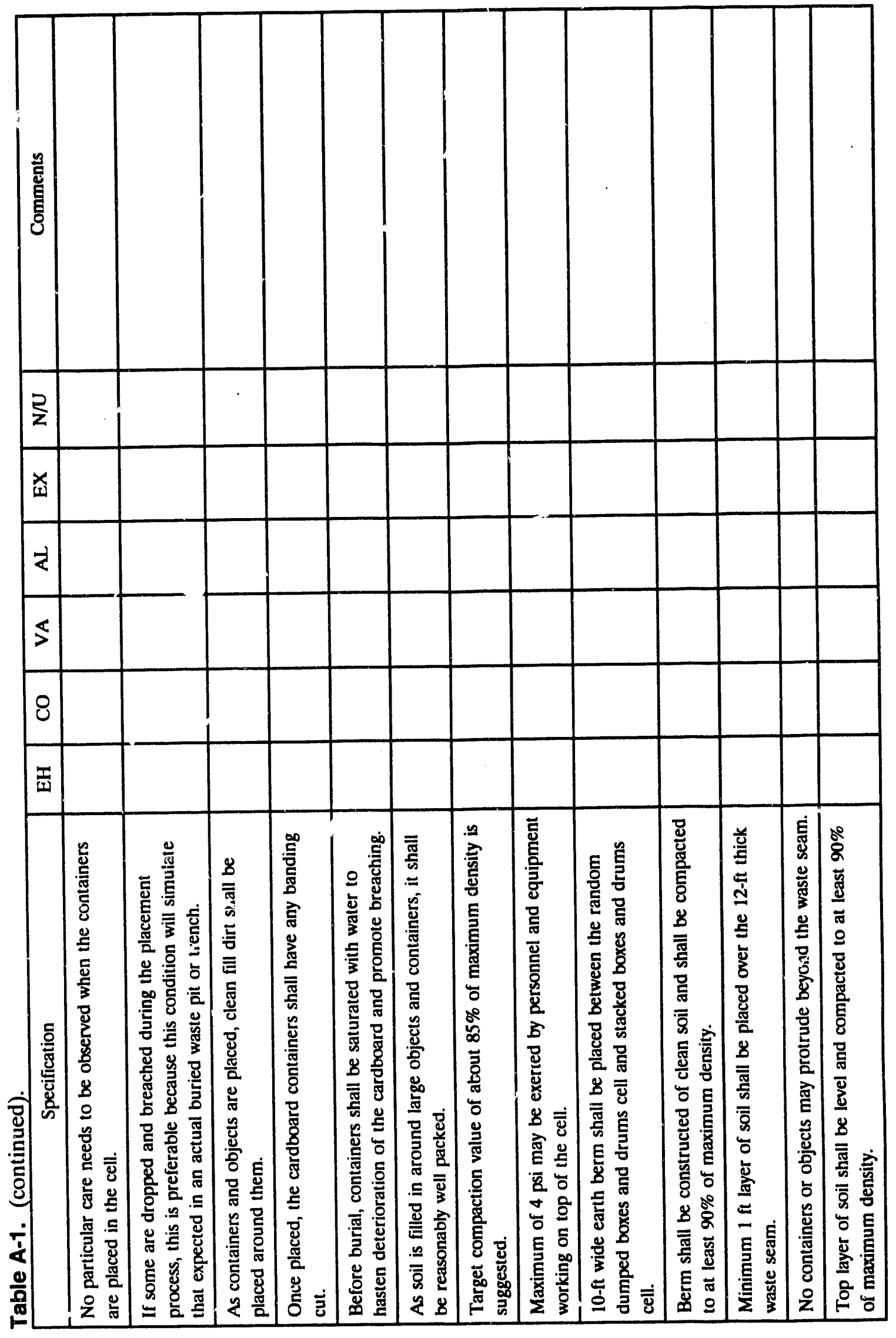




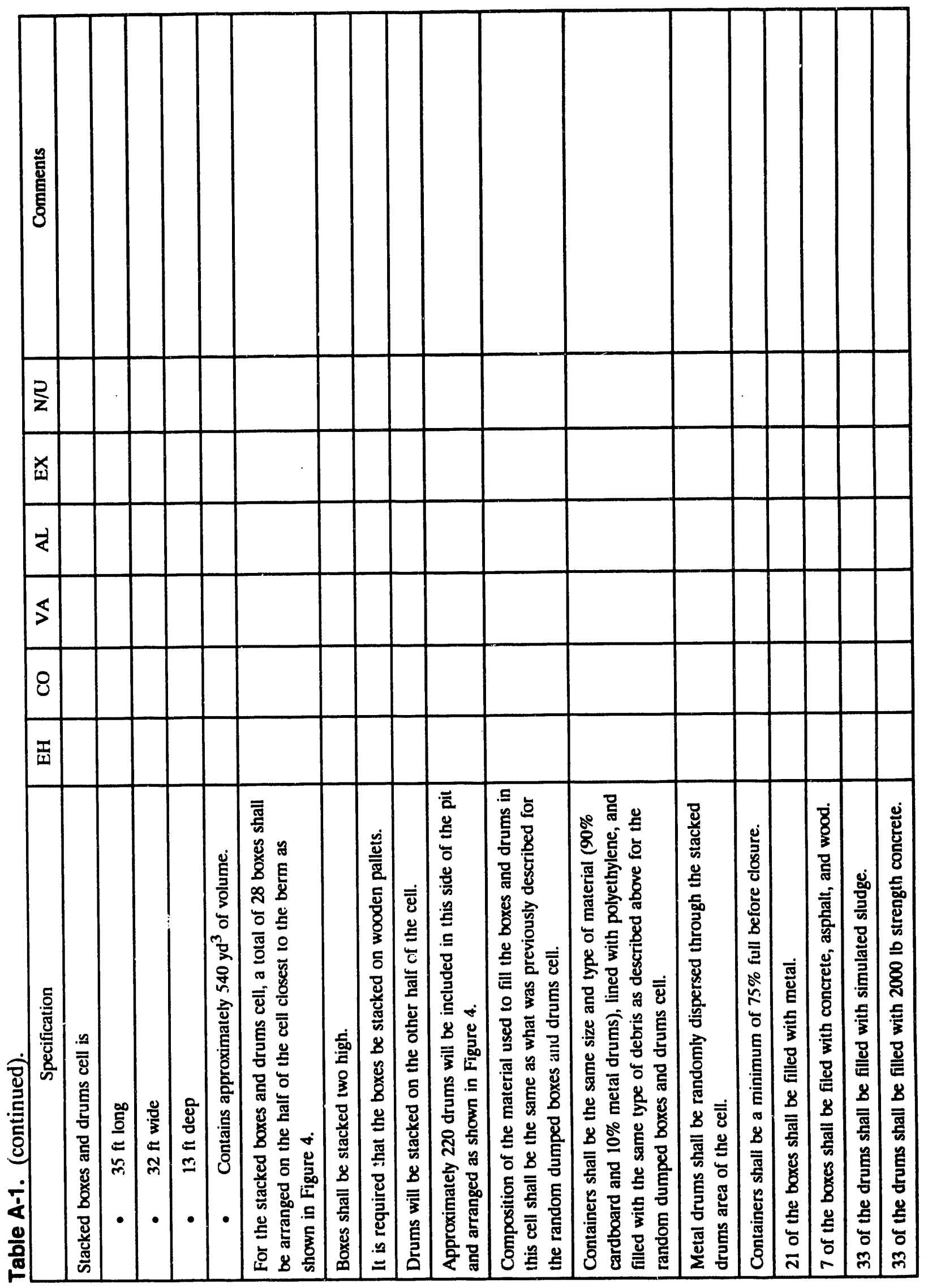




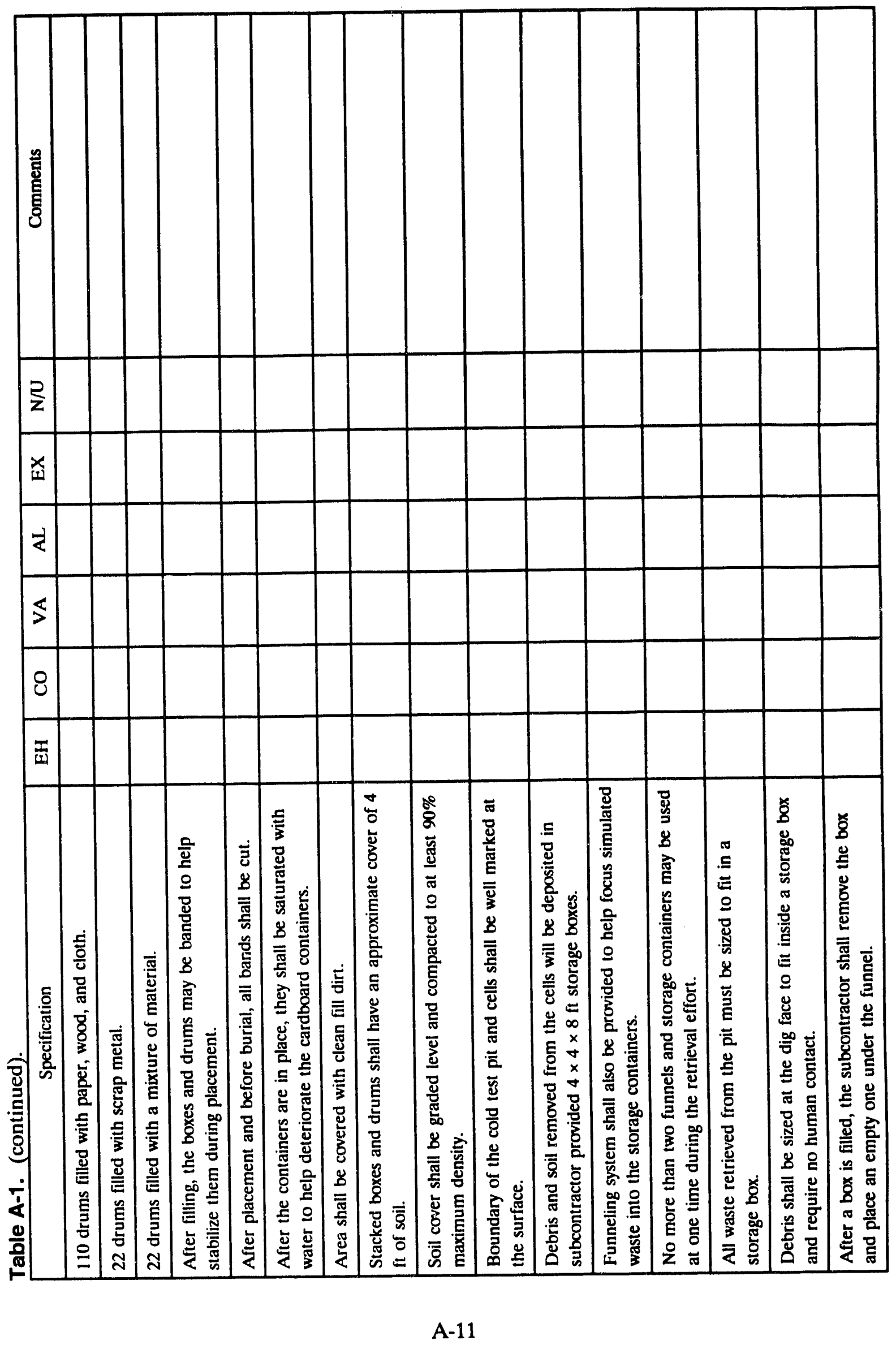




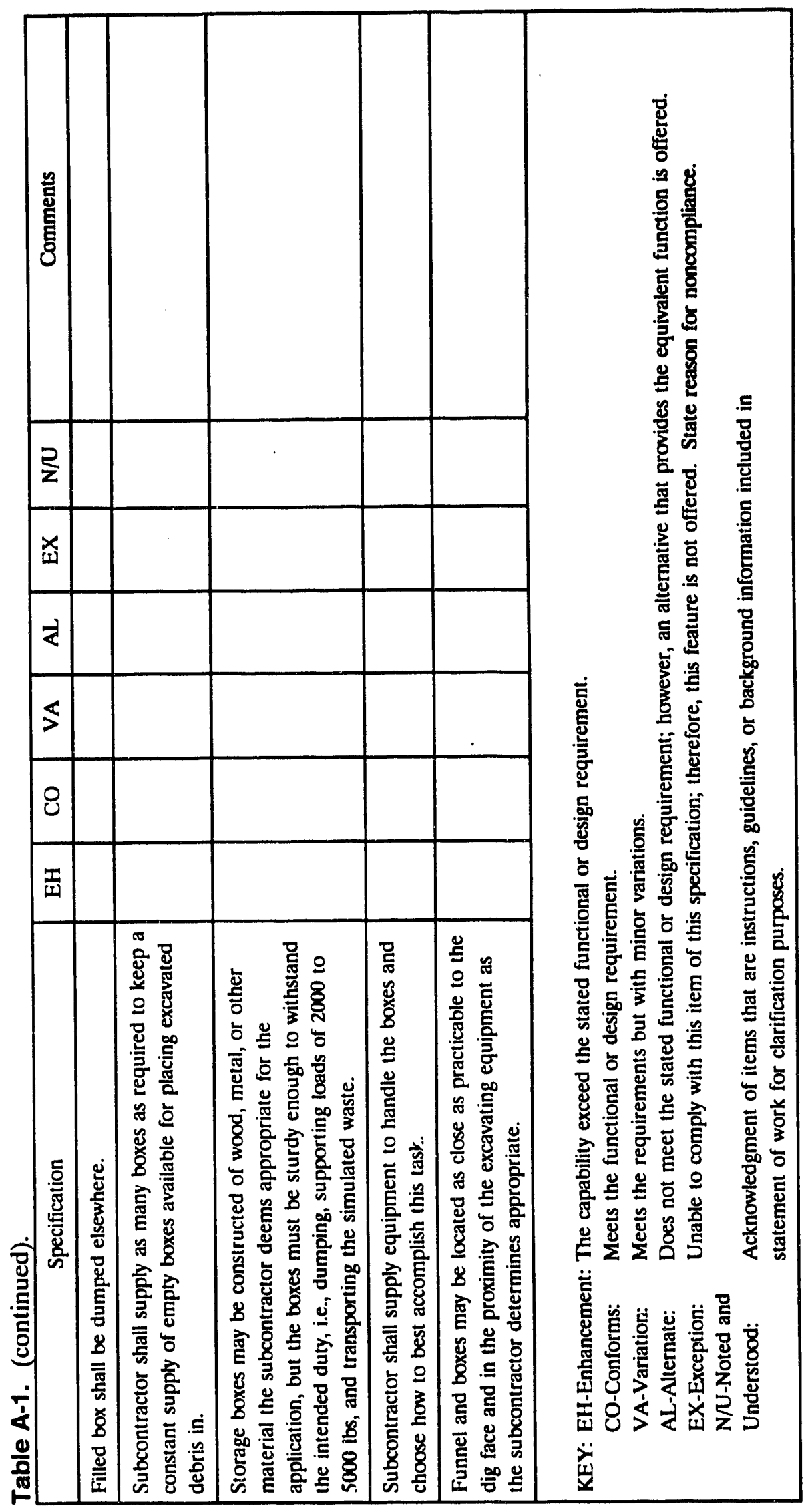



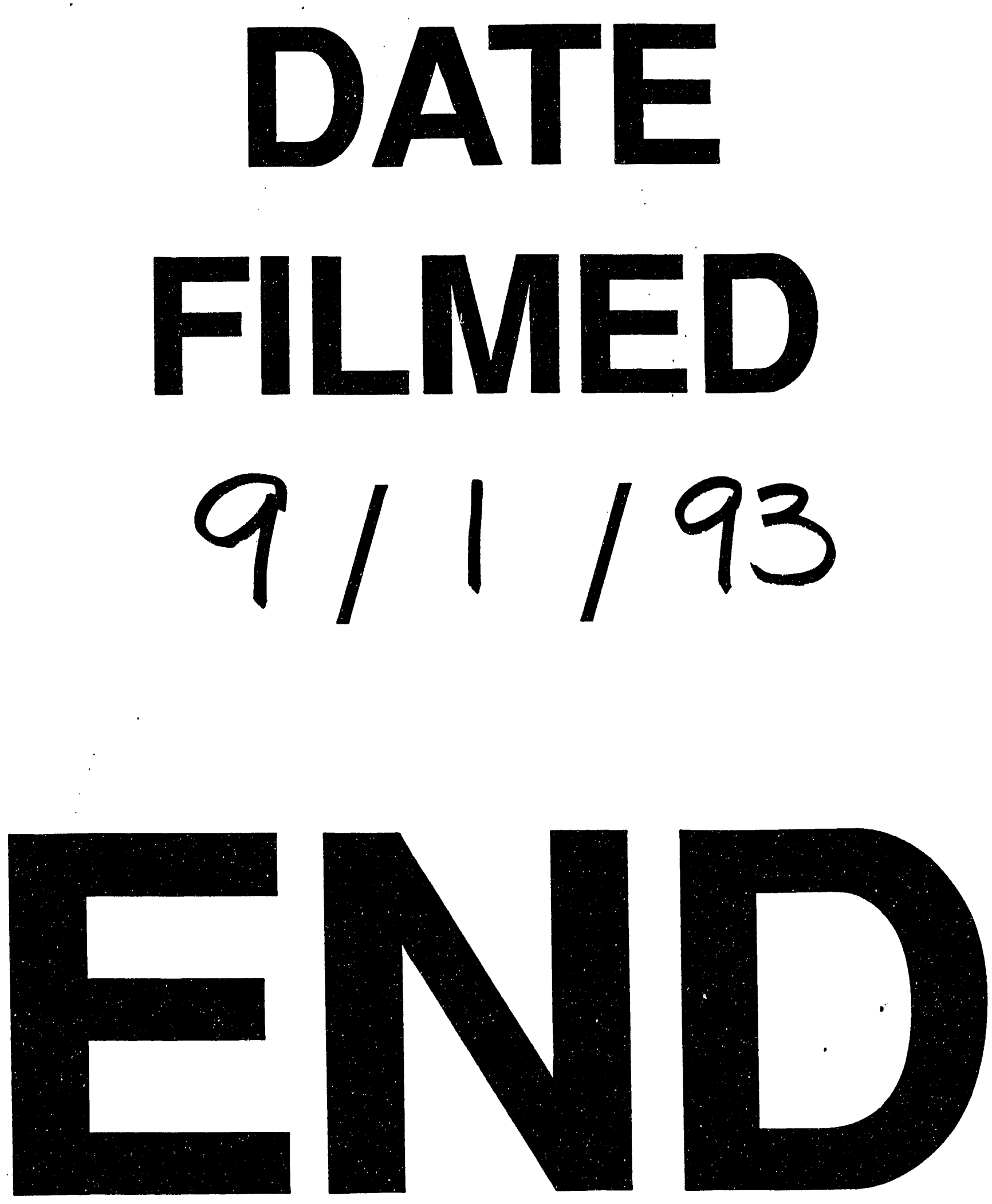
